\title{
Okul öncesi eğitim kurumlarında çalışan yöneticilerin yaratıcı liderlik özelliklerinin çeşitli değişkenler bağlamında incelenmesi*
}

\author{
Investigation of creative leadership characteristics of administrators \\ working in preschool education institutions in the context of various \\ variables $^{*}$
}

Banu Dikmen Ada ${ }^{1}$, Rengin Zembat ${ }^{2}$

\begin{abstract}
Makale Geçmişi
Geliş : : 16 Şubat 2021

Düzeltme : 2 Haziran 2021

Kabul : 21 Haziran 2021
\end{abstract}

\section{Makale Türü}

Araștırma Makalesi

Article History

Received : 16 February 2021

Revised : 2 June 2021

Accepted : 21 June 2021

Article Type

Research Article
Öz: Araştırmada, okul öncesi eğitim kurumları ve bünyesinde okul öncesi eğitim sınıfı bulunan kurumların yöneticilerinin yaratıcı liderlik özelliklerinin belirlenmesi amaçlanmış ve bu özelliklerin belirlenen demografik değişkenler açısından farklılık gösterip göstermediği de incelenmiştir. Araştırma tarama modelinde tasarlanmıştır. Araştırma verileri "Yaratıcı Liderlik Ölçeği” (YLÖ) ve "Kişisel Bilgi" formu ile toplanmıştır. Ölçeğin Cronbach Alfa katsayısı 0.986 düzeyindedir. Araştırma bulgularına göre; yöneticilerin ölçek ve alt ölçekler için puan ortalamaları 3,2069-3,4891 arasındadır. Yöneticilerin "YLÖ”, "Mesleki ve Kişisel Gelişime Odaklanma” ve "Değişim ve Dönüşüme Odaklanma” alt ölçeğine ait puanlarında kadın yöneticiler lehine anlamlı farklılık bulunmaktadır. Yöneticilerin YLÖ puanlarının öğrenim düzeyi Çocuk Gelişimi Eğitimi Ön Lisans olan yöneticilerin lehine, "YLÖ” ve "Değişim ve Dönüşüme Odaklanma" alt ölçeğine ait puanlarının ise üniversitelerin çocuk yuvasında ve özel anaokulunda çalışan yöneticilerinin lehine "Mesleki ve Kişisel Gelişime Odaklanma” alt ölçeği puanları da özel anaokulu yöneticilerinin lehine anlamlı farklllık gösterdiği bulunmuştur. Araştırmada yöneticilerin yaratıcı liderlik özelliklerinin orta düzeyin üzerinde olduğu; katılımcıların cinsiyet, öğrenim düzeyi ve kurum türüne göre yaratıcı liderlik özelliklerinin farklılaştığı sonuçlarına ulaşılmıștır. Anahtar Kelimeler: Okul Öncesi Eğitim, Liderlik, Yaratıcı Liderlik, Yönetici

Abstract: This study aimed to determine the creative leadership characteristics of the administrators of preschool education institutions, and it was designed in a scanning model. The data in the study were collected with the 'Personal Information' form and the 'Creative Leadership Scale' (CLS). The Cronbach alpha reliability coefficient of the scale was 0.986 , and the mean scores of the administrators for scales and subscales were between 3.2069 and 3.4891. There was a significant difference in favor of female administrators in the subscale scores of 'CLS', 'Focus on Change and Transformation' and 'Focus on Professional and Personal Development' of managers. In addition, it was observed that there were significant differences in the findings according to the education level and the type of institution they work with. It was also found that the creative leadership characteristics of the managers were above the middle level. Thus, it was concluded that the creative leadership characteristics of the participants differ according to gender, education level and institution type.

Keywords: Administrator, Creative Leadership, Leadership, Preschool Education

\footnotetext{
* Bu çalışma araştırmacının Prof. Dr. Rengin Zembat danışmanlığında yürütülen "Yaratıcı Liderlik Ölçeği'nin Geliştirilmesi ve Okul Öncesi Yönetici ve Öğretmenlerinin Yaratıcı Liderlik Özelliklerinin İncelenmesi” başlıklı 2020 yılı öncesi yapılmış olan doktora tezinin yöneticiler ile ilgili olan kısmindan türetilmiștir

${ }^{2}$ Eskișehir Osmangazi Üniversitesi, Eğitim Fakültesi, Temel Eğitim Bölümü, bdada@ogu.edu.tr, ORCID: https://orcid.org/0000-0001-7490-2056 ${ }^{3}$ Maltepe Üniversitesi, Eğitim Fakültesi, Temel Eğitim Bölümü, renginzembat@maltepe.edu.tr, ORCID: https://orcid.org/0000-0002-2377-8910
} 


\section{SUMMARY}

\section{Introduction}

Creativity and creative leadership concepts are important in schools (Vandenberghe, 1995). Institutions need creative leadership to support innovative approaches and individual creative behaviours (Sisk, 2001). Creative leadership can be achieved not only with the effort and activity of a particular department, person or group but also with a perfect leadership and management process (Marşap, 1999).

Administrators have an essential place in preschool education institutions (Taymaz, 2003), and they are responsible for providing quality education to children in institutions (Zembat, 2005; 2001). In this context, developing the leadership characteristics of managers is necessary. Creative leaders allow their students to think and do different things by preparing the conditions, environment and possibilities so that all students can change their lives (Stoll and Temperley, 2009). On the basis of the statements made, it can be deduced that preschool education institutions should motivate teachers and that teachers should motivate students.

In this context, educational institutions play a critical role in the development of administrators, teachers and creative leadership qualities. Furthermore, responsible leadership quality is important for managers. The following questions are sought on this page: How long will managers continue (focus on change, coaching and collaboration, professional and personal development and problem solving and critical thinking)? Are important quotations on the leadership qualities of managers relative to their demographic data?

\section{Method}

This study aimed to determine the 'creative leadership characteristics of preschool administrators in public and private preschool education institutions and public and private primary schools'. Moreover, the research methodised according to the descriptive survey model tried to find an answer to the following question: What levels of creative leadership do managers have? The questionnaires used in this study are the 'CLS' developed by the researcher to examine the creative leadership characteristics of managers and the 'Personal Information' form to collect information about demographic characteristics of the managers. The analysis of the data obtained from this study, frequency, percentage calculations and arithmetic averages were employed to determine the views of the managers on creative leadership qualities. Additionally, the KruskalWallis $\mathrm{H}$ test was applied to determine whether the creative leadership questionnaire and sub-factor scores differ according to age, education level, branch, the duration of service as a teacher, the length of service as a manager and the type of institution.

\section{Results}


Generally, there is a significant difference in favour of female managers in terms of the 'CLS', 'Focus on Change and Transformation' and 'Focus on Professional and Personal Development' subscale scores of managers. There is no significant difference in the other sub-dimensions of the creative leadership scale according to the gender variable. It has been determined that the 'CLS' scores of the administrators generally show a significant difference in favour of the administrators whose education level is Child Development and Education Associate Degree. In addition, there is no significant difference in the other sub-dimensions of the creative leadership scale according to the education level variable. There is also no significant difference in the scores of the administrators of the scales and sub-scales according to the variables of age, branch, length of service in teaching and service time in management. The 'CLS' and 'Focus on Professional and Personal Development' subscale scores of the administrators are generally in favour of the administrators working in private kindergartens, whilst the 'Focus on Change and Transformation' subscale scores are significantly in favour of the administrators working in private preschools and university kindergartens. It has been determined to differ, and in the other sub-dimensions of the scale, there is no significant difference according to the variable of institution type.

\section{Conclusion and Discussion}

According to the research, it was revealed that the creative leadership characteristics of the managers are above the middle level in scale and in all dimensions of the scale. There is a significant difference in favour of female managers in the subscale scores of 'CLS', 'Focus on Change and Transformation' and 'Focus on Professional and Personal Development' of managers. On the basis of the results of the research conducted by Litchka, Babaoğlan and Beycioğlu (2009, p.1-2) and the research by Aral and Köksal (1999) and the literature information, the gender variable does not cause a difference in the concept of creativity. Further, it has been determined that the scores of the 'Creative Leadership' scale of the administrators generally show a significant difference in favour of the administrators whose education level is Child DevelopmentPreschool Teaching-Kindergarten Teaching Associate Degree. The fact that it turned out to be in favour of those who have this education level was interpreted as the study may be because the administrators are generally older in the city centre and that the administrators who work in public and private primary schools have more managerial experiences. The fact that there was a significant difference in favour of private kindergartens in terms of 'creative leadership', 'focusing on change and transformation' and 'focusing on professional and personal development' in the dimensions of the study, in favour of private kindergartens, was interpreted in a way that private kindergartens attach more importance to their own development than public schools to create innovation and difference. Hence, it is thought that creative leadership qualities are essential in creating the qualified society of the future. It is also affirmed that the working managers of educational institutions should gain creative leadership qualities so that they can fulfil the specified functions. 


\section{GİRIŞ}

Liderlik, kurumların yönetim anlayışında post modern (modern sonrası) ve çağdaş yaklaşımlar tarafindan oluşturulan temel kavramlardan birisi (Koçel, 2007) olmasının yanı sıra organizasyonların başarısında da temel kavramlardan birisi olarak kabul da edilmektedir (Özalp, 1999). Morland (2008)'a göre liderlik; kurumun geleceğini yaratmak için sorumluluğun farklı bireyler arasında paylaştırıldığı yaratıcı ve ortak bir süreçtir. Sessa (1998)'e göre liderlik; çalışanların yaratıcı düşüncelerini desteklemek; Abra (1994)'a göre ise yeni fikirlerin başarılarını eleştirel bakış açısı ile garantilemek olarak ifade edilmektedir (Mumford, Connelly ve Gaddis, 2003). Kurumlar yenilikçi yaklaşımları ve bireysel yaratıcı davranışları desteklemek için yaratıcı liderliğe gereksinim duymaktadırlar (Sisk, 2001). Moolenaar, Karsten, Sleegers ve Zijlstra (2009)'a göre kurumların amaçlarına ulaşabilmelerinde ve eğitimcilerin geleceğe uyumlarının sağlanmasında, eğitimcilerde birlikte öğrenme isteğinin oluşturulması, birlikte yeni bilgilerin oluşturulması, birlikte yeni uygulamaların oluşturulması ve birlikte değişim sağlanması önem taşımaktadır (akt. Moolenaar vd., 2010). Okullardaki yaratıcı ortamlar ile ilgili olarak yapılan araştırmalara göre de okulların gelişim sürecinin başarılı ya da başarısız olmasında başarı için harcanan çabanın yenilikle desteklenmesi gerektiği ifade edilmektedir (Moolenaar, Daly ve Sleegers, 2010). Okullarda, yaratıc1lı ve yaratıc1 liderlik kavramlarının oluşturulması önemlidir (Vandenberghe, 1995). Yaratıcı liderlik, insan kaynaklarını bir bütün olarak işletebilme, bilimsel, akılcı, sistematik, yaratıcı düşünceye odaklanma, değişim, gelişim ve yeni girişimleri yönetebilme ve motivasyonu ortaya çıkarma olarak tanımlanabilir. Yaratıcı liderlik, sadece belli bir kişi ya da grub veya bölümün faaliyet ve çabalarıyla değil, mükemmel bir liderlik ve yönetim süreciyle gerçekleştirilebilir (Marşap, 1999). Senge ve Deming ise kurumların karşılaştıkları birçok problem ve hatanın yaratıcı liderlere sahip olmamalarından kaynaklandığını ifade etmektedirler (Tichy, 1997; akt. Agbor, 2008, s.41). Araştırma sonuçlanna dayanarak günümüzde yöneticilerinin öncelikli ve temel görevi; organizasyonların karşılaştıkları problemleri tanımak, tam olarak kavramak ve yeni çözüm önerilerini oluşturmak (Marşap, 1999) olarak ifade edilebilir. Liderlik; öğrencilerin öğrenmelerinde, okul kültürünün yaratılmasında, öğretme kalitesinin arttırılmasında ve öğrenmenin zenginleştirilmesiyle ilgili koşulların sağlanması ve farklılaştırılmasında da önemlidir (Leithwood vd., 2006; akt. Stoll ve Temperley, 2009). Yaratıcı liderler kurumun değişimi, takipçilerin cesaretlendirilmesi, kurum için yapılacakların nedenlerinin açıklanması ve yapılacaklar için alternatif yolların araştırılmasını sağlarlar (Agbor, 2008). Yaratıcı liderler, tüm öğrencilerinin yaşamlarını değiştirebilmeleri için koşulları, çevreyi ve olanakları hazırlayarak öğrencilerinin farklı şeyler düşünmelerine ve yapmalarına olanak tanırlar (Stoll ve Temperley, 2009). 
Erken çocukluk eğitimi ile ilgili yapılan araştırmalarda da erken çocukluk döneminde yaşanan olumlu deneyimlerin çocukların mevcut gelişimlerini ve ilerleyen dönemlerdeki gelişimlerini de büyük ölçüde etkilediği ifade edilmektedir (Khim, 2003). Okul öncesi eğitim kurumlarının temel görevi çocuklara nitelikli bir eğitim sunmaktır ve kurumlarda verilen nitelikli eğitim çocuklarda öğrenmeye istekli olmayı ve öğrenmeyi arttırarak, onların yaşamları boyunca başarılı olmalarını sağlamaktadır (Zembat, 2005; 2001). Okul öncesi eğitim kurumlarında yöneticiler de önemli bir yere sahiptir (Taymaz, 2003) ve kurumlarda çocuklara kaliteli eğitimin verilmesinden sorumludurlar (Zembat, 2005; 2001).

Geleceğin etkili bir biçimde oluşturulabilmesinde eğitim kurumlarının yaratıcı liderlik yaklaşımı ile yönetilmesi de önem taşımaktadır. Bu bağlamda eğitim kurumların yaratıcı liderlik yaklaşımıyla yönetilebilmesi için yaratıc liderlik özelliklerine sahip yöneticilere ihtiyaç duyulmaktadır. Yukarıda belirtilen açıklamalara dayanarak eğitim kurumlarının kendilerinden beklenen işlevi yerine getirmelerinde yaratıcı liderlik kavramının önemli bir faktör olduğu belirtilebilir. Bireylerin, hızlı bir biçimde değişim, gelişim ve küreselleşmenin yaşandığ günümüz dünyasının sahip olduğu problemlerle başa çıkabilmelerinde, problemlerin doğru olarak tanımlanması ve yaratıcı bir biçimde eleştirel bakış açısı ile çözümlenmesinde liderlik ve yaratıcı liderlik kavramlarının önem kazandığı görülmektedir. Eğitim sisteminin diğer birimlerinde olduğu gibi okul öncesi eğitim kurumları yöneticilerinin yaratıcı liderlik özelliklerini geliştirmelerinin eğitim kurumlarından beklenen görev ve sorumlulukların olumlu olarak ifa edilmesinde önemli bir etken olduğu söylenebilir. Yaratıcı liderlik özelliklerinin yöneticiler ve öğretmenler aracıllı̆ı ile öğrencilere kazandırılabileceği ve öğrencilerin gerçek yaşamın karmaşık problemleriyle baş etmelerinde etkili olan yaratıcı liderlik özelliklerini kullanmalarına olanak tanıyacağı düşünülmektedir. Bu nedenle bireylere yaratıcı liderlik özelliklerinin kazandırılmasında okul öncesi eğitim kurumlarına da önemli görevler düşmektedir. Bireylerin sahip olmaları gerektiği düşünülen bazı özellikler ise; 21. Yüzyıllındaki değişim ve gelişmelere ayak uydurabilme, karşılaşılan problem durumları ile baş edebilme, yaratıcı problem çözebilme, eleştirel düşünebilme, analiz ve sentez yapabilme, bilimsel düşünme, akılcı düşünme, sistematik düşünme, yaratıcı düşünceye odaklanma, yaratıcıllı̆̆ ve yeni girişimleri yönetebilme, kendisinin ve diğerlerinin motivasyonu sağlama olarak ifade edilebilir. Yapılan açıklamalara dayanarak, okul öncesi eğitim kurumlarının belirledikleri hedeflere ulaşmalarında da yaratıcı liderlerin öğretmenleri, öğretmenlerin ise öğrencilerine rol model olarak onlara yaratıcı liderlik özelliklerini kazandırılmaları önemlidir. Liderlik becerilerinin öğretilebilir olmasından dolayı bireylerin etkili liderlik becerileri geliştirilebilir (Sternberg, 2005). Bu bağlamda eğitim kurumları yaratıcı liderlik özelliklerinin geliştirilmesinde önemlidir ve belirtilen özelliklerin kazandırılmasınında da öncelikle eğitim yöneticilerinin sorumluluğunda olduğu belirtilebilir. 
Yapılan alanyazın taramasında kurumların ve eğitim kurumlarının yönetim sürecinde yaratıcı liderliğin önemli olduğuna vurgu yapılmaktadır. Ancak yapılan alan yazın taramasında eğitim araştırmaları içinde yaratıcılık ve yaratıcı özellikler konusunu inceleyen çok sayıda araştırma olmasına rağmen, yaratıcı liderlik konusunun önemi dikkate alındığında yaratıcı liderlik kavramını ele alan az sayıda araştırmaya rastlanılmıştır. Bu araştırmalardan bazıları; Mueller, Goncalo ve Kamdar (2011, s.494) tarafından yaratıcı liderliğin tanınması ve yaratıcı fikrin ifade edilmesinin liderlik potansiyeli algısını negatif olarak etkileyip etkilemediğinin incelendiği araştırmada yaratıcı fikirlerin ifade edilmesi ve liderlik potansiyeli arasında negatif ilişki bulunduğunu ve etkili liderler seçmenin önemli olduğuna vurgu yapılmıştır. Stoll ve Temperley (2008) tarafindan yapılan araştırmadan elde edilen bulgulara göre yaratıcı liderliğin pozitif farklılıklara gereksinim duyduğunu belirtilmiştir. Hong ve Lu (2005, s.1) tarafindan yapılan okul gelişiminde yaratıcı liderlik konusunun incelendiği durum çalışmasında elde edilen verilere göre okul yönetimiyle ilgili olarak "toplumda olan toplumu geliştirir” ilkesinin önemli olduğu ifade edilmiştir. Sisk (2001, s.2) tarafindan "yönetici yardımcıları, yöneticiler ve yönetim kurulu başkanlarının yaratıcı liderlikleri” adlı araştırmadan elde edilen verilere göre de araştırmaya katılan yöneticiler, yaratıcı liderin sahip olması gereken nitelikleri; stratejik düşünme, kültür yaratma, duyarlılık, öngörü, çok yönlü olma, sabırlı ve anlayışlı olmak olarak belirtmişlerdir. Liderliğin altın kurallarının; dürüstlük, doğruluk, güçlendirme, yetki, eşitlik, sayg1, yaratıcılık, mizah, eğlence, yeniden düşünme ve adalet olduğunu ve liderliğin ise; ortak amaçlara ulaşmak için yaratıcı enerjiye odaklanarak değişiklikleri uygulamak olduğunu belirtmişlerdir (Sisk, 2001, s.4). Ayrıca yapılan alan yazın taramasında yaratıcı ortam ve bireylerin performansının arttırılmasında liderliğin etkisine yönelik olarak yapılan araştırmalardan bazıları ise; Ekvall vd., yaratıcı ortam, yaratıcı liderlik ve grup yaratıcıllı̆ı arasında pozitif ilişki olduğu (Ekvall, 1990; Ekvall and Tangerberg-Andersson, 1986; Nyström, 1979, 1990) ve yaratıc1 ortamlarda ki "liderlerin uyum biçimi”" ve "sıcak ve pozitif ortamlardaki gruplar" arasında da güçlü bir ilişki olduğu ifade edilmektedir (akt. Rickards ve Moger, 2000, s.275). Politis (2004, s.26-27) yaratıc1 olduğu düşünülen çalışanlar ile dönüşümcü-dönüştürücü liderlik özellikleri ve çalışma ortamının yaratıcılığ1 arasında önemli ölçüde pozitif ilişki bulunduğunu; Jaussi ve Dionne (2003, s.492) beklenilmeyen liderlik davranışları ve lideri takip edenlerin bireysel yaratıcı performansları hem de grupların yaratıcı performansları arasındaki grup düzeyinde grup performansındaki yaratıcılı̆̆1 destekleyen değerler ve grup seçimi ve grup yaratıcıllı̆g arasında içsel motivasyonun yaratıcılığ1 önemli derecede etkilediğini; Mumford vd., (2000) tarafından yapılan bilişsel süreçleri konu alan bir başka çalışmada da yaratıcı bilişte etkili olan iki önemli faktörün "uzmanlık" ve "beceri kazanma süreci” olduğu ve gerçekte yaratıcı grupların liderliğinin etkili performans ile ilişkili olduğunu bulgulamışlardır (akt. Mumford vd., 2003, s.413). Tierney, Farmer ve Graen (1999) liderlerin yaratıcı 
problem çözme becerileri, beceri edinme süreci ve üretimi ile grup üyelerinin icat etme, karar verme ve yaratıcılıkları arasında doğrudan ilişki olduğu, yaratıcılık ve etkililik ile liderlik özellikleri ve takipçilerin değişimi arasında ilişki olduğunu bulgulamışlardır (akt. Mumford vd., 2003, s.413). Redmond, Mumford ve Teach (1993) takipçilerin performansının liderin problemleri tanımlaması ve probleme takipçilerin katkılarına ve yaratıcılıklarına olan inançlarına bağlı olduğunu, dönüşümcü liderlik ile grubun akıcılık ve esnekliği arasında pozitif ilişki olduğu (Sosik, Avolio ve Kahai, 1998) sonucuna ulaşmışlardır (Sosik, Kahai ve Avolio, 1999;akt. Hughes, 2005, s.5). Yaratıcı grupların liderliğinde uzmanlığın rolünün incelenmesiyle ile ilgili ilk çalışmayı Andrews ve Farris (1967) yapmışlardır. Bu çalışmada grup üyelerinin yaratıcı performans algılarına dayanarak liderlerin sahip oldukları teknik becerilerin grup performansında en etkili faktör olduğunu bulmuşlardır (Mumford vd., 2003, s.413). Wang ve Rode (2010, s.1106) çalışanların lider ile özdeşleşmesinin ve yaratıcı ortamın çalışanların yaratıcılığı ile ilişkili olduğunu; Hughes (2005) pozitif duyguların, güven, ruh hali ve şeffaflı̆̆ı takipçilerin yaratıcı performansında önemli olduğunu belirtmiştir. Moolenaar, Daly ve Sleegers (2010, s.623-624), dönüşümcü liderliğin yaratıcı okul ortamı ile pozitif yönde ilişkili olduğu, yöneticilerin sosyal ağlarda yer alan pozisyonlarının okulun yaratıcı ortamı ile ilişkili olduğu, birçok yöneticinin profesyonel ve kişisel tavsiyelerinin öğretmenlerin öğrenme isteği ile ilişkili olduğu ve iş ilişkilerinin merkezinde dönüşümcü liderlik ve yaratıcı ortamın ilişkili olduğunu bulgulamışlardır. Bass ve Avolio, (2000) dönüşümcü liderlik ve öğretmenlerin sınıf içi liderlikleri arasında güçlü ve pozitif ilişki olduğunu bulmuşlardır (Pounder, 2006, s.540). Shin vd., (2004, s.301) erken çocuklukta görülen liderlik özelliklerini; “dinamik ve karizmatik özellikler ile sahiplenme” ve "sınıf içindeki yüksek farkındalık" olarak iki ana temada ifade etmişler ve genç liderlerin sosyal güçlerini arkadaşları ve öğretmenleri ile olan ilişkilerinden aldıklarını, aynı zamanda arkadaşları ve öğretmenleri ile içerideki ve dışarıdaki etkileşimlerinin de sosyal güçlerinde etkili olduğu sonucuna ulaşmışlardır. Yamaguchi (2004) tarafından çocukların gelişmekte olan liderdik algıları ile ilgili olarak yapılan araştırmadan elde edilen sonuçlara göre de liderlikte görev ve ilişkiye odaklanmanın grup düzenleme ve grup seçimi ile pozitif yönde ilişkili olduğu görülmüştür. Ulaşılan araştırmalardan elde edilen sonuçlara dayanarak yaratıcı liderlik kavramın günümüzün değişen koşullarında kurumların ve bireylerin amaçlarına ulaşmaları için gereken özellikleri kazandırmaya yönelik önemli bir kavram olduğu belirtilebilir. Ayrıca yaratıcı liderlik ve yaratıcı ortamın yönetici, öğretmenler ve öğrencilerin performanslarını da olumlu yönde etkilediği düşünüldüğünde bu araştırmanın yapılması ve araştırmadan elde edilen bulguların; yöneticilerinin yaratıcı liderlik özelliklerinin belirlenerek desteklenmesi ve yeni liderlik yaklaşımlarından olan "yaratıcı liderlik" yaklaşımının önemine dikkat çekmesi açısından da önem taşımaktadır. Ayrıca okul öncesi eğitim kurumu yöneticileri, öğretmenleri ve öğrencilerini küresel dünyanın hızla değișen koşullarına 
hazırlanmaları için önemli görülen "yaratıcı liderlik” yaklaşımı ile ilgili farkındalık oluşturmalarına ve çocukların yaratıcı liderlik özelliklerini kazanmalarına yönelik eğitim yaklaşımlarının oluşturulmasına da katkı sağlayacağının düşünülmesi de araştırmanın önemli olan başka bir boyutunu oluşturmaktadır.

\section{Amaç}

Araştırmanın amacı resmi ve özel okul öncesi eğitim verilen kurumlarda çalışmakta olan yöneticilerinin (müdür-müdür yardımcıları) yaratıcı liderlik özelliklerinin belirlenmesidir. Araştırmanın genel amacı doğrultusunda belirlenen alt amaçlarında da; yöneticilerin yaratıcı liderlik özellikleri (Değişim ve Dönüşüme Odaklanma; Koçluk Yapma ve Birlikte Çalışmaya Odaklanma; Problem Çözme ve Eleştirel Düşünmeye Odaklanma; Mesleki ve Kişisel Gelişime Odaklanma) ne düzeydedir?" ve "Yöneticilerin yaratıcı liderlik özellikleri (Değişim ve Dönüşüme Odaklanma; Koçluk Yapma ve Birlikte Çalışmaya Odaklanma; Problem Çözme ve Eleştirel Düşünmeye Odaklanma; Mesleki ve Kişisel Gelişime Odaklanma) yöneticilerin demografik özelliklerinden “cinsiyet, öğrenim düzeyi, yaş, branş, yöneticilikteki hizmet süresi, öğretmenlikteki hizmet süresi ve çalışılan kurum türü” değişkenleri açısından farklılık göstermekte midir? Sorularına yanıt aranmıştır.

\section{YÖNTEM}

\section{Araştırma Modeli}

$\mathrm{Bu}$ araştırmada resmi ve özel okul öncesi eğitim verilen kurumlarda çalışmakta olan yöneticilerinin (müdür-müdür yardımcıları) yaratıcı liderlik özelliklerinin belirlenmesi amaçlanmıştır. Bu amaç doğrultusunda araştırmada, nicel tarama modellerinden biri olan betimsel tarama modeli kullanılmıştır. Tarama araştırmalarında seçilen örneklemin tutumlanını, görüşlerini, özelliklerini veya davranışlarını betimlemek amacıyla nicel araştırmalarda kullanılan işlem basamakları kullanılır (Creswell, 2012). Tarama modeli, halen var olan ya da geçmişte var olan bir durumu var olduğu biçimiyle tasvir etmeyi amaçlayan araştırma yaklaşımlarıdır (Karasar, 2012). Betimsel tarama modeli ise, geniş gruplar üzerinde yürütülen, gruptaki bireylerin bir olgu ve olayla ilgili görüşlerinin, tutumlarının alındığı, olgu ve olayların betimlenmeye çalışıldığı araştırmalardır (Karakaya, 2012, s.59). Bu araştırma yöntemi nesnelerin, toplumların, kurumların yapısını ve olayların işleyişini tanımlamak amacıyla kullanılır (Cohen, Manion \& Morrison, 2007). Bu araştırmada da, okul öncesi eğitim verilen kurumların yöneticilerinin yaratıcı liderlik özellikleri "cinsiyet, öğrenim düzeyi, yaş, branş, yöneticilikteki hizmet süresi, öğretmenlikteki hizmet süresi ve çalışılan kurum türü” 
değişkenleri açısından nicel veri toplama stratejileri kullanılarak incelendiğinden betimsel tarama modeli kullanılmıştır.

\section{Çalışma Evreni}

$\mathrm{Bu}$ araştırmanın çalışma evreni Eskişehir ili merkezindeki okul öncesi eğitim kurumları (resmi ve özel) ile bünyesinde okul öncesi eğitim sınıfi bulunan kurumlarda çalışmakta olan yöneticiler (müdürler ve müdür yardımcıları) oluşturmaktadır. Araştırmada çalışma evreninin tümüne ulaşılmaya çalışıldığı için çalışma evreninden örneklem alma yoluna gidilmemiştir. Araştırmaya katılan yöneticilerden (müdürler ve müdür yardımcıları) demografik özelliklerine ait elde edilen sonuçlar sırasıyla; araştırmaya katılan yöneticilerin cinsiyet değişkenine göre 137’si erkek, 51’i kadın katılımcılardan; yaş değişkenine göre 104'ü 41 yaş ve üstü, 40’1 31-35 arası, 38’i 36-40 yaş arası ve 6's1 26-30 yaş arası katılımcılardan; öğrenim düzeyi değişkenine göre 106'sı ön lisans, 39'u lisans, 17’si Çocuk Gelişimi/Anaokulu/Okul Öncesi Öğretmenliği lisans, 9’u Çocuk Gelişimi/Anaokulu/Okul Öncesi Öğretmenliği ön lisans, 4’ü lisans tamamlama, 4'ü Eğitim Enstitüsü, 3’ü yüksek lisans, 2'si Çocuk Gelişimi/Anaokulu/Okul Öncesi Öğretmenliği Yüksek Lisans, 2'si Açık Öğretim Fakültesi Okul Öncesi Öğretmenliği, 2'si Kız Meslek Lisesi öğrenim düzeyine sahip katılımcılardan; branş değişkenine göre 85’i ilk öğretim okulları ve özel okul öncesi eğitim kurumlarında yönetici olarak çalışmakta olan branş öğretmenleri (Beden Eğitimi, Bilgisayar, Fen ve Teknoloji, İngilizce, Matematik, Psikoloji, Resim İş Öğretmenliği-Görsel Sanatlar, Sosyal Bilgiler, Sosyal Çalışma, Teknoloji Tasarım, Türkçe), 71’i sınıf öğretmeni ve 32'si okul öncesi eğitim öğretmenlerinden; öğretmenlikteki hizmet süresi değişkenine göre yöneticilerin 69’u 21 yll ve üstü, 46's1 11-15 y1l aras1, 37'si 16-20 y1l aras1, 27'si 6-10 y1l aras1, 7'si 1-5 y1l aras1 ve 2'si 1 y1ldan az öğretmenlik hizmet süresine sahip katılımcılardan; yöneticilikteki hizmet süresi değişkenine göre 56's1 1-5 y1l arası, 40’1 6-10 y1l aras1, 29’u 16-20 y1l aras1, 26's1 11-15 y1l aras1, 20'si, 21 y1l ve üstü ve 17'si 1 yıldan az yöneticilik süresine sahip katılımcılardan; çalışılan kurum türü değişkenine göre 139’u resmi ilköğretim okulu, 21’i MEB bağımsız anaokulu, 16’s1 özel anaokulu, 6’s1 özel ilköğretim okulu, 4'ü kız meslek lisesi uygulama anaokulu ve 2'si üniversite çocuk yuvasında çalışmakta olan katılımcılardan oluşmaktadır.

\section{Veri Toplama Araçları}

Araştırmada kullanılan veri toplama araçları olarak; araştırmacı tarafindan geliştirilen "Yaratıcı Liderlik Ölçeğì" ve "Kişisel Bilgi Formu” kullanılmıştır. Çalışma evreninin demografik özellikleri; cinsiyet, yaş, görev, branşınız, öğrenim düzeyi, öğretmenlikteki hizmet süresi, yöneticilikteki hizmet süresi ve çalışılan kurum türü hakkında bilgi toplamak amacıyla araştırmacılar tarafından geliştirilmiş 
8 soruluk bir formdur. Yaratıcı Liderlik Ölçeği (YLÖ); 107 maddelik dörtlü likert türü ölçektir. Yaratıcı Liderlik Ölçeği’ni geliştirmek için öncelikle liderlik ve yaratıcı liderlik ile ilgili alanyazın taranarak "Yöneticilerin ve Çalışanların (Öğretmenlerin) Yaratıcı Liderlik Kavramı Hakkındaki Yorumlarına İlişkin Soru Listesi” oluşturmuştur. Bu liste eğitim bilimleri alanı öğretim üyeleri tarafindan incelenmiş ve listeye son hali verilmiştir. Soru listesinde yer alan açık uçlu sorular aracılığ1 ile elde edilen görüşler ve alanyazın bilgilerine dayanarak araştırmacılar tarafından yönetici ve öğretmenlerin yaratıcı liderlik özelliklerini belirlemek amacıyla madde havuzunda yer alan maddelerden eğitim alanında uzman beş öğretim üyesinin görüşleri de alınarak Yaratıcı Liderlik Ölçeği’nde yer alması gerektiği düşünülen maddeler belirlenmiş 161 maddeden oluşan 4'lü likert tipi ölçeğin ilk hali hazırlanmıştır. Ölçme aracının kapsam geçerliği Lawshe tekniği kullanılarak eğitim bilimleri alanı öğretim üyelerinin görüşleri alınarak ölçekte yer alan maddelerin geçerlilik/uygunluluk düzeyleri belirlenmiştir. Geçerlilik/uygunluluk düzeylerinin belirlenmesinde ise \%90-100 oranında uzlaşılması ölçü olarak kabul edilerek, ölçütü karşılamayan maddeler ölçekten çıkarılarak ölçek maddelerinin geçerliliği tespit edilmiştir. Ölçeğin yapı geçerliğinin incelenmesi için açımlayıcı faktör analizi temel bileşenler yöntemiyle yapılmıştır. Faktör analizinden adlandırılabilir ve yorumlanabilir faktörler elde edebilmek için de varimax döndürme yöntemi kullanılmıştır. Verilerin faktör analizi için yeterliğini saptamak için Kaiser-Meyer-Olkin Testi; ölçeğin her bir maddesinin faktör analizine uygunluğu Measures of Sampling Adequacy Testi, verilerin çok değişkenli normal dağılıma sahip olup olmadığını belirlemek amacıyla ise Barlett Küresellik Testi yapılmıştır. Yapılan geçerlik ve güvenilirlik analizlerinin sonuçlarına göre ölçek 107 maddeye indirgenmiştir. Yaratıcı Liderlik Ölçeği’ne ait açımlayıcı faktör analizi değerleri $\mathrm{KMO}=, 964$, $^{2}$ Barlett test $(5671)=40508,971 \mathrm{p}=, 000$ 'dir. YLÖ'nin açılkanan toplam varyans miktarı \%50.773'dir. YLÖ'nün yapı geçerliğinde elde edilen faktörler arası korelasyonlar değerleri .706 ile .799, faktörler ile toplam ölçek arasındaki korelasyon değerleri ise .877 ile .924 arasında değişen pozitif ve .01 anlamlılık düzeyinde $(\mathrm{p}<.01)$, anlamlı değerlere sahiptir. Yapılan faktör analizi sonucuna göre ölçek dört alt faktörde toplanmıstır. Ölçeğin faktörleri; "Değişim ve Dönüşüme Odaklama” 43 maddeden, "Koçluk Yapma ve Birlikte Çalışmaya Odaklanma" 19 maddeden, "Problem Çözme ve Eleştirel Düşünmeye Odaklanma" 25 maddeden ve "Mesleki ve Kişisel Gelişime Odaklanma" 20 maddeden oluşmaktadır. Ölçeğin derecelendirilmesinde katılımcılar "yaratıcı liderlik" özelliklerini algılama sıklıklarını her maddede belirtilen biçimde puanlamaktadırlar. Sıklık derecelemesi, her zaman (4 puan), genellikle ( 3 puan), bazen ( 2 puan) ve hiçbir zaman (1 puan) biçimindedir. Yaratıcı Liderlik Ölçeği’nin Cronbach Alfa katsayısı 0.986 düzeyindedir. Ölçeğin alt faktörlerine ait Cronbach Alfa katsayıları ise 0.947 ile 0.967 arasında değerler almaktadır. Bu araştırma da toplam 
ölçeğe ait elde edilen Cronbach Alfa katsayısı 0.962 düzeyindedir. Ölçeğin alt faktörlerine ait Cronbach Alfa katsayıları ise 0.948 ile 0.963 arasında değerler almaktadır.

\section{Verilerin Toplanmas1}

YLÖ'nün çalışma evreninde uygulanması için Eskişehir İl MEM' B.30.2.MAR.0.45.00.00/1169 sayılı izni doğrultusunda araştırmacılar tarafından çalışma grubuna uygulanmıştır. Bu çalışma 2020 yılı öncesinde tamamlandığı için etik kurul izin belgesi bulunmamaktadır. Araştırmada çalışma evreninin tümüne ulaşılmaya çalışıldığ 1 için evrenden örneklem alma yoluna gidilmemiştir. Araştırmacılar çalışma evreninde yer alan kurumlara giderek katılımcılar ile görüşme yöntemini kullanarak uygulama öncesinde katılımcılara; araştırmanın amacı, önemi ve veri toplama araçlarının özellikleri ile ilgili bilgiler vermişlerdir. Bu görüşmeler sırasında ölçeklerin nasıl doldurulması gerektiğini de örnek bir madde üzerinden göstermişler ve bu bilgilerin yer aldığı bir açıklama ve teşekkür mektubu ile birlikte ölçme araçları 188 katılımcıya verilmiş ve katılımcılar tarafından doldurulan formlar araştırmacılar tarafindan doldurma işlemi tamamlandıktan hemen sonra veri kaybı yaşanmadan toplanmıştır. Araştırma verilerinin belirtilen biçimde toplanması yaklaşık olarak bir ay sürmüştür.

\section{Verilerin Çözümlenmesi}

Okul öncesi eğitim kurumları (resmi ve özel) ile bünyesinde okul öncesi eğitim sınıfı bulunan kurumlarda çalışmakta olan yöneticilerin (müdürler ve müdür yardımcıları) yaratıcı liderlik özelliklerini incelemek için katılımcılardan elde edilen veriler "SPSS" paket programılla çözümlenmiştir. Verilerin çözümlenmesinde sırasıyla; katılımcıların demografik özelliklerinin değerlendirilmesinde frekans ve yüzde değerleri kullanılmıştır. Verilerin çok değişkenli normal dağıllimdan gelip gelmediğini belirlemek için ise Barlett Küresellik Testi (Bartlett's Test of Sphericity) yapılmıştır (KMO=,964, x2 Barlett test $(5671)=40508,971 \mathrm{p}=, 000)$ ve veriler normal dağ 1 llım göstermediği için YLÖ ve alt faktörlerinin değerlendirilmesinde; yöneticilerin cinsiyetleri açısından incelenmesinde Mann Whitney $U$ testi; yöneticilerin yaş, branş, öğrenim düzeyi, yöneticilikteki hizmet süresi, öğretmenlikteki hizmet süresi ve çalısılan kurum türü açısından incelenmesinde ise Kruskal Wallis-H testi ile elde edilen sonuçlarda farkın hangi gruplardan oluştuğunun saptanmasında ise Mann Whitney U testi ile yapılmıştır ve anlamlılık düzeyi olarak .05 değeri baz alınmıştır. 


\section{BULGULAR}

Bu bölümde yöneticilerin YLÖ ve alt ölçeklerine ait puanları ve yöneticilerin demografik özelliklerinin incelendiği araştırma amaçlarına yönelik olarak yapılan istatistiksel analizlerden elde edilen bulgulara yer verilmiştir.

Tablo 1. Yöneticilerin Yaratıcı Liderlik Ölçeği ve alt ölçeklere ait puanları

\begin{tabular}{llll}
\hline Ölçek ve alt ölçekler & $\mathbf{N}$ & $\overline{\mathbf{X}}$ & Ss \\
\hline Yaratıcı Liderlik & 153 & 3,469 &, 355 \\
Değişim ve Dönüşüme Odaklanma & 157 & 3,489 &, 364 \\
Koçluk Yapma ve Birlikte Çalışmaya Odaklanma & 172 & 3,329 &, 427 \\
Problem Çözme ve Eleştirel Düşünmeye Odaklanma & 167 & 3,461 &, 397 \\
Mesleki ve Kişisel Gelişime Odaklanma & 172 & 3,206 &, 368 \\
\hline
\end{tabular}

Tablo 1'de yöneticilerin yaratıcı liderlik özelliklerinin belirlenmesi amacıyla yapılan analiz sonucuna göre yöneticilerin YLÖ ve ölçeğe ait alt ölçeklere ait puan ortalamalarının 3,206-3,489 arasında olduğu bulgulanmıştır. Elde edilen bulguya göre yöneticilerin yaratıcı liderlik özelliklerinin orta derecenin üzerinde olduğu söylenebilir.

Tablo 2. Yöneticilerin cinsiyet değişkeni Mann Whitney U testi sonucu

\begin{tabular}{|c|c|c|c|c|c|c|c|}
\hline Ölçek ve alt ölçekler Puan & Gruplar & $\mathbf{n}$ & SO & ST & $\mathbf{U}$ & $\mathbf{z}$ & $\mathrm{p}$ \\
\hline \multirow[t]{3}{*}{ Yaratıc1 Liderlik } & Kadin & 43 & 89,53 & 3850,00 & \multirow[t]{3}{*}{1826,000} & \multirow[t]{3}{*}{$-2,188$} & \multirow[t]{3}{*}{,029* } \\
\hline & Erkek & 110 & 72,10 & 7931,00 & & & \\
\hline & Toplam & 153 & & & & & \\
\hline Değişim ve Dönüşüme & Kadın & 45 & 93,98 & 4229,00 & \multirow[t]{3}{*}{1846,000} & \multirow[t]{3}{*}{$-2,619$} & \multirow[t]{3}{*}{,009* } \\
\hline \multirow[t]{2}{*}{ Odaklanma } & Erkek & 112 & 72,98 & 8174,00 & & & \\
\hline & Toplam & 157 & & & & & \\
\hline Koçluk Yapma ve Birlikte & Kadın & 50 & 97,07 & 4853,50 & \multirow[t]{3}{*}{2521,500} & \multirow[t]{3}{*}{$-1,786$} & \multirow[t]{3}{*}{,074 } \\
\hline \multirow[t]{2}{*}{ Çalışmaya Odaklanma } & Erkek & 122 & 82,17 & 10024,50 & & & \\
\hline & Toplam & 172 & & & & & \\
\hline \multirow{3}{*}{$\begin{array}{l}\text { Problem Çözme ve Eleştirel } \\
\text { Düşünmeye Odaklanma }\end{array}$} & Kadın & 48 & 91,19 & 4377,00 & \multirow[t]{3}{*}{2511,000} & \multirow[t]{3}{*}{$-1,222$} & \multirow[t]{3}{*}{222} \\
\hline & Erkek & 119 & 81,10 & 9651,00 & & & \\
\hline & Toplam & 167 & & & & & \\
\hline \multirow{3}{*}{$\begin{array}{l}\text { Mesleki ve Kişisel Gelişime } \\
\text { Odaklanma }\end{array}$} & Kadın & 50 & 99,92 & 4996,00 & \multirow[t]{3}{*}{2379,000} & \multirow[t]{3}{*}{$-2,271$} & \multirow[t]{3}{*}{,023* } \\
\hline & Erkek & 122 & 81,00 & 9882,00 & & & \\
\hline & Toplam & 172 & & & & & \\
\hline
\end{tabular}

Tablo 2'de görüldüğüü üzere yöneticilerin YLÖ ve alt ölçeklerinin cinsiyet değişkenine göre grupların farklılık sınaması için yapılan analize göre yöneticilerin "YLÖ puanları $(U=1826,000$; ₹ =-2,188; $p<.05)$ " ile "Değişim ve Dönüşüme Odaklanma" ( $U=1846,000 ; z=-2,619 ; p<.05)$ ve "Mesleki ve Kişisel Gelişime Odaklanma" alt ölçekleri ( $U=2379,000 ; z=-2,271 ; p<.05)$ puanlanının gruplara ait sıra ortalamaları arasında istatistiksel olarak anlamlı farklar bulunmuştur. Cinsiyet değişkenine göre bulunan farklılıklar "YLÖ” ile "Mesleki ve Kişisel Gelişime Odaklanma” ve "Değişim ve Dönüşüme Odaklanma" alt ölçeklerinde kadın yöneticilerin lehinedir. Buna göre kadın 
yöneticilerin, erkek yöneticilere göre "YLÖ” ile "Mesleki ve Kişisel Gelişime Odaklanma" ve "Değişim ve Dönüşüme Odaklanma" düzeyleri daha yüksektir. Yöneticilerin "Koçluk Yapma ve Birlikte Çalışmaya Odaklanma" ( $U=2521,500 ; z=-1,786 ; p>.05)$ ve "Problem Çözme ve Eleştirel Düşünmeye Odaklanma” ( $\left.U=2511,000 ; z^{\prime}=-1,222 ; p>.05\right)$ alt ölçeklerine ait puanlar arasındaki fark istatistiksel olarak anlamlı bulunmamıştır. Buna göre, kadın ve erkek yöneticilerin "Problem Çözme ve Eleştirel Düşünmeye Odaklanma” ve "Koçluk Yapma ve Birlikte Çalışmaya Odaklanma" düzeyleri farkl1l1k göstermemektedir.

Tablo 3. Yöneticilerin yaş değişkeni Kruskal Wallis-H testi sonuçları

\begin{tabular}{|c|c|c|c|c|c|c|}
\hline Ölçek ve Alt Ölçekler Puan & Guruplar & $\mathbf{n}$ & SO & $\mathrm{X}^{2}$ & sd & $\mathrm{p}$ \\
\hline \multirow[t]{5}{*}{ Yaratıc1 Liderlik } & $26-30$ yaş & 6 & 107,25 & 3,751 & 3 & 290 \\
\hline & $31-35$ yaş & 37 & 74,00 & & & \\
\hline & $36-40$ yaş & 31 & 82,24 & & & \\
\hline & 41 yaş ve üstü & 79 & 74,05 & & & \\
\hline & Toplam & 153 & & & & \\
\hline \multirow{5}{*}{$\begin{array}{l}\text { Değişim ve Dönüşüme } \\
\text { Odaklanma }\end{array}$} & $26-30$ yaş & 6 & 113,00 & 4,111 & 3 & 0,250 \\
\hline & $31-35$ yaş & 37 & 73,01 & & & \\
\hline & 36-40 yaş & 34 & 77,03 & & & \\
\hline & 41 yaş ve üstü & 80 & 80,06 & & & \\
\hline & Toplam & 157 & & & & \\
\hline \multirow{5}{*}{$\begin{array}{l}\text { Koçluk Yapma ve Birlikte } \\
\text { Çalışmaya Odaklanma }\end{array}$} & $26-30$ yaş & 6 & 120,00 & 6,552 & 3 & ,088 \\
\hline & $31-35$ yaş & 38 & 90,04 & & & \\
\hline & 36-40 yaş & 36 & 96,58 & & & \\
\hline & 41 yaş ve üstü & 92 & 78,91 & & & \\
\hline & Toplam & 172 & & & & \\
\hline \multirow{5}{*}{$\begin{array}{l}\text { Problem Çözme ve Eleştirel } \\
\text { Düşünmeye Odaklanma }\end{array}$} & $26-30$ yaş & 6 & 105,50 & 4,801 & 3 & 0,187 \\
\hline & 31-35 yaş & 37 & 81,28 & & & \\
\hline & $36-40$ yaş & 33 & 97,23 & & & \\
\hline & 41 yaş ve üstü & 91 & 78,89 & & & \\
\hline & Toplam & 167 & & & & \\
\hline \multirow{5}{*}{$\begin{array}{l}\text { Mesleki ve Kişisel Gelişime } \\
\text { Odaklanma }\end{array}$} & $26-30$ yaş & 6 & 128,00 & 7,294 & 3 & 0,063 \\
\hline & $31-35$ yaş & 38 & 85,72 & & & \\
\hline & $36-40$ yaş & 36 & 96,79 & & & \\
\hline & 41 yaş ve üstü & 92 & 80,09 & & & \\
\hline & Toplam & 172 & & & & \\
\hline
\end{tabular}

Tablo 3’te görüldüğü üzere yöneticilerin YLÖ ve alt ölçeklerinin yaş değişkenine göre grupların farklılık sınaması için yapılan analize göre yöneticilerin "YLÖ $\left(X^{2}(3)=3,751, p>0,05\right)$ ” ve "Değişim ve Dönüşüme Odaklanma $\left(X^{2}(3)=4,111, p>0,05\right)$ ", "Koçluk Yapma ve Birlikte Çalışmaya Odaklanma" $\left(X^{2}(3)=6,552, p>0,05\right)$, "Problem Çözme ve Eleştirel Düşünceye Odaklanma $\left(X^{2}\right.$ (3)=4,801, $p>0,05)$ " ve “Mesleki ve Kişisel Gelişime Odaklanma $\left(X^{2}(3)=7,294, p>0,05\right)$ " alt ölçeklerinden elde edilen olasılık değerleri anlamlılık dereceleri 0,05 ’ten büyük olduğundan yaş değişkeni için grupların sıralı ortalama puanlarındaki fark istatistiksel olarak anlamlı bulunmamaktadır. Buna göre, yöneticilerin yaşları "Yaratıcı Liderlik”, "Değissim ve Dönüşüme 
Odaklanma", "Koçluk Yapma ve Birlikte Çalışmaya Odaklanma", "Problem Çözme ve Eleştirel Düşünceye Odaklanma" ve "Mesleki ve Kişisel Gelişime Odaklanma" özelliklerini etkilememektedir.

Tablo 4. Yöneticilerin öğrenim düzeyi değişkeni Kruskal Wallis-H testi sonuçları

\begin{tabular}{|c|c|c|c|c|c|c|}
\hline $\begin{array}{l}\text { Ölçek ve Alt Ölçekler } \\
\text { Puan }\end{array}$ & Guruplar & $\mathbf{n}$ & SO & $\mathbf{X}^{2}$ & sd & $\mathrm{p}$ \\
\hline \multirow[t]{11}{*}{ Yaratıc1 Liderlik } & Kız Meslek Lisesi & 2 & 69,25 & 17,560 & 9 & ,041* \\
\hline & AÖF Okul Öncesi Öğretmenliği & 2 & 51,25 & & & \\
\hline & Çocuk Gelişimi Bölümü Ön Lisans & 6 & 125,50 & & & \\
\hline & $\begin{array}{l}\text { Çocuk Gelişimi/Anaokulu/Okul } \\
\text { Öncesi Öğretmenliği Lisans }\end{array}$ & 15 & 78,03 & & & \\
\hline & $\begin{array}{l}\text { Çocuk Gelişimi/Anaokulu/Okul } \\
\text { Öncesi Öğretmenliği Yüksek Lisans }\end{array}$ & 2 & 85,50 & & & \\
\hline & Lisans & 32 & 90,77 & & & \\
\hline & Eğitim Enstitüsü & 3 & 103,17 & & & \\
\hline & Lisans tamamlama & 3 & 49,83 & & & \\
\hline & Yüksek Lisans & 3 & 38,33 & & & \\
\hline & Ön lisans & 85 & 70,20 & & & \\
\hline & Toplam & 153 & & & & \\
\hline \multirow{11}{*}{$\begin{array}{l}\text { Değişim ve Dönüşüme } \\
\text { Odaklanma }\end{array}$} & Kız Meslek Lisesi & 2 & 71,25 & 14,239 & 9 & 0,114 \\
\hline & AÖF Okul Öncesi Öğretmenliği & 2 & 68,50 & & & \\
\hline & Çocuk Gelişimi Bölümü Ön Lisans & 6 & 126,75 & & & \\
\hline & $\begin{array}{l}\text { Çocuk Gelişimi/Anaokulu/Okul } \\
\text { Öncesi Öğretmenliği Lisans }\end{array}$ & 15 & 82,03 & & & \\
\hline & $\begin{array}{l}\text { Çocuk Gelişimi/Anaokulu/Okul } \\
\text { Öncesi Öğretmenliği Yüksek Lisans }\end{array}$ & 2 & 85,75 & & & \\
\hline & Lisans & 34 & 88,59 & & & \\
\hline & Eğitim enstitüsü & 4 & 86,63 & & & \\
\hline & Lisans tamamlama & 3 & 35,50 & & & \\
\hline & Yüksek lisans & 3 & 42,50 & & & \\
\hline & Ön lisans & 86 & 74,05 & & & \\
\hline & Toplam & 157 & & & & \\
\hline \multirow{11}{*}{$\begin{array}{l}\text { Koçluk Yapma ve } \\
\text { Birlikte Çalışmaya } \\
\text { Odaklanma }\end{array}$} & Kız Meslek Lisesi & 2 & 86,50 & 13,048 & 9 & 0,160 \\
\hline & AÖF Okul Öncesi Öğretmenliği & 2 & 36,50 & & & \\
\hline & Çocuk Gelişimi Bölümü & 8 & 116,81 & & & \\
\hline & $\begin{array}{l}\text { Çocuk Gelişimi/Anaokulu/Okul } \\
\text { Öncesi Öğretmenliği Lisans }\end{array}$ & 17 & 94,24 & & & \\
\hline & $\begin{array}{l}\text { Çocuk Gelişimi/Anaokulu/Okul } \\
\text { Öncesi Öğretmenliği Yüksek Lisans }\end{array}$ & 2 & 103,25 & & & \\
\hline & Lisans & 36 & 100,32 & & & \\
\hline & Eğitim enstitüsü & 3 & 110,00 & & & \\
\hline & Lisans tamamlama & 4 & 56,25 & & & \\
\hline & Yüksek lisans & 3 & 69,33 & & & \\
\hline & Ön lisans & 95 & 79,10 & & & \\
\hline & Toplam & 172 & & & & \\
\hline \multirow{6}{*}{$\begin{array}{l}\text { Problem Çözme ve } \\
\text { Eleştirel Düşünceye } \\
\text { Odaklanma }\end{array}$} & Kuz Meslek Lisesi & 2 & 73,75 & 10,381 & 9 & 0,321 \\
\hline & AÖF Okul Öncesi Öğretmenliği & 2 & 42,50 & & & \\
\hline & Çocuk Gelişimi Bölümü Ön Lisans & 7 & 122,93 & & & \\
\hline & $\begin{array}{l}\text { Çocuk Gelişimi/Anaokulu/Okul } \\
\text { Öncesi Öğretmenliği Lisans }\end{array}$ & 17 & 88,29 & & & \\
\hline & $\begin{array}{l}\text { Çocuk Gelişimi/Anaokulu/Okul } \\
\text { Öncesi Öğretmenliği Yüksek Lisans }\end{array}$ & 2 & 99,75 & & & \\
\hline & Lisans & 34 & 93,03 & & & \\
\hline
\end{tabular}




\begin{tabular}{|c|c|c|c|c|c|c|}
\hline $\begin{array}{l}\text { Ölçek ve Alt Ölçekler } \\
\text { Puan }\end{array}$ & Guruplar & $\mathbf{n}$ & SO & $\mathbf{X}^{2}$ & sd & $\mathrm{p}$ \\
\hline & Eğitim enstitüsü & 4 & 81,25 & & & \\
\hline & Lisans tamamlama & 4 & 72,38 & & & \\
\hline & Yüksek lisans & 3 & 47,83 & & & \\
\hline & Ön lisans & 92 & 79,49 & & & \\
\hline & Toplam & 167 & & & & \\
\hline Mesleki ve Kişisel & Kız Meslek Lisesi & 2 & 88,75 & 12,545 & 9 & 0,184 \\
\hline \multirow[t]{10}{*}{ Gelişime Odaklanma } & AÖF Okul Öncesi Öğretmenliği & 2 & 73,25 & & & \\
\hline & Çocuk Gelişimi Bölümü Ön Lisans & 8 & 115,75 & & & \\
\hline & $\begin{array}{l}\text { Çocuk Gelişimi/Anaokulu/Okul } \\
\text { Öncesi Öğretmenliği Lisans }\end{array}$ & 17 & 89,35 & & & \\
\hline & $\begin{array}{l}\text { Çocuk Gelişimi/Anaokulu/Okul } \\
\text { Öncesi Öğretmenliği Yülssek Lisans }\end{array}$ & 2 & 94,00 & & & \\
\hline & Lisans & 36 & 105,03 & & & \\
\hline & Eğitim enstitüsü & 4 & 72,00 & & & \\
\hline & Lisans tamamlama & 3 & 62,83 & & & \\
\hline & Yüksek lisans & 3 & 54,17 & & & \\
\hline & Ön lisans & 95 & 78,96 & & & \\
\hline & Toplam & 172 & & & & \\
\hline
\end{tabular}

Tablo 4’te görüldüğü üzere yöneticilerin YLÖ ve alt ölçeklerinin öğrenim düzeyi değişkenine göre grupların farklılık sınaması için yapılan analize göre YLÖ olasılık değeri 17,560, anlamlılık derecesi de .0,05’ten düşük olduğundan öğrenim düzeyine göre farklılaşmaktadır $\left(X^{2}(3)=17,560, p<0,05\right)$. Bu farkl1llğa neden olan öğrenimi Çocuk Gelişimi Bölümü Ön lisans olan yöneticilere ait puanlar diğer gruplardan anlamlı derecede fazladır, sırasıyla bunu öğrenim düzeyi Eğitim Enstitüsü, Lisans, Çocuk Gelişimi/Anaokulu/Okul Öncesi Öğretmenliği Yüksek Lisans, Çocuk Gelişimi/Anaokulu/Okul Öncesi Öğretmenliği Lisans, Ön lisans, Kız Meslek Lisesi, AÖF Okul Öncesi Öğretmenliği, Lisans tamamlama ve Yüksek Lisans olan yöneticilerin izlediği görülmektedir. “Koçluk Yapma ve Birlikte Çalışmaya Odaklanma $\left(X^{2}(9)=13,048, p>0,05\right)$ ”, "Değişim ve Dönüşüme Odaklanma $\left(X^{2}(9)=14,239\right.$, $\left.p>0,05\right)$ ", "Mesleki ve Kişisel Gelişime Odaklanma $\left(X^{2}\right.$ (3)=12,545, $p>0,05)$ " ve "Problem Çözme ve Eleştirel Düşünceye Odaklanma $\left(X^{2}(3)=10,381\right.$, $p>0,05)$ " alt ölçeklerinden elde edilen olasıllk değerleri anlamlllık dereceleri 0,05'ten büyük olduğundan öğrenim düzeyi puanları istatistiksel olarak farklılaşmamaktadır. Buna göre, yöneticilerin öğrenim düzeyleri "Değişim ve Dönüşüme Odaklanma”, “Koçluk Yapma ve Birlikte Çalışmaya Odaklanma", "Problem Çözme ve Eleştirel Düşünceye Odaklanma" ve "Mesleki ve Kişisel Gelişime Odaklanma” özelliklerini etkilememektedir. Bu işlemin ardından, yaratıcı liderlik özellikleri için saptanan anlamlı farklılığın kaynaklandığı grupları saptamak için tamamlayıcı karşılaştırma testlerinden Mann Whitney U Testi uygulanarak elde edilen sonuçlardan anlamlı fark bulunan gruplara ait sonuçlar aşağıdaki tabloda yer almaktadır. 
Tablo 5. Yöneticilerin öğrenim düzeyi değişkeni yaratıcı liderlik ölçeği Mann Whitney U testi sonucu

\begin{tabular}{|c|c|c|c|c|c|c|}
\hline Gruplar & $\mathbf{n}$ & SO & ST & $\mathbf{u}$ & $\mathbf{z}$ & $\mathrm{p}$ \\
\hline $\begin{array}{l}\text { Çocuk Gelişimi/Anaokulu/Okul } \\
\text { Öncesi Öğretmenliği Ön Lisans }\end{array}$ & 6 & 15,50 & 93,00 & 18,000 & $-2,103$ & ,035* \\
\hline $\begin{array}{l}\text { Çocuk Gelişimi/Anaokulu/Okul } \\
\text { Öncesi Öğretmenliği Lisans }\end{array}$ & 15 & 9,20 & 138,00 & & & \\
\hline Toplam & 21 & & & & & \\
\hline $\begin{array}{l}\text { Çocuk Gelişimi/Anaokulu/Okul } \\
\text { Öncesi Öğretmenliği Ön Lisans }\end{array}$ & 6 & 6,33 & 38,00 & 1,000 & $-2,066$ & ,039* \\
\hline Lisans Tamamlama & 3 & 2,33 & 7,00 & & & \\
\hline Toplam & 9 & & & & & \\
\hline $\begin{array}{l}\text { Çocuk Gelişimi/Anaokulu/Okul } \\
\text { Öncesi Öğretmenliği Ön Lisans }\end{array}$ & 6 & 6,50 & 39,00 & ,000 & $-2,324$ & ,020* \\
\hline Yüksek Lisans & 3 & 2,00 & 6,00 & & & \\
\hline Toplam & 9 & & & & & \\
\hline $\begin{array}{l}\text { Çocuk Gelişimi/Anaokulu/Okul } \\
\text { Öncesi Öğretmenliği Ön Lisans }\end{array}$ & 6 & 77,25 & 465,00 & 67,500 & $-2,999$ & ,003* \\
\hline Ön Lisans & 85 & 43,79 & 3721,00 & & & \\
\hline Toplam & 91 & & & & & \\
\hline Lisans & 32 & 70,92 & 2269,50 & 978,500 & $-2,333$ & ,020* \\
\hline Ön Lisans & 85 & 54,51 & 4633,50 & & & \\
\hline Toplam & 117 & & & & & \\
\hline
\end{tabular}

Tablo 5'te yapılan analizler sonucunda farklılı̆̆ın, öğrenim düzeyi Çocuk Gelişimi/Anaokulu/Okul Öncesi Öğretmenliği ön lisans olan yöneticiler ve öğrenim düzeyi Çocuk Gelişimi/Anaokulu/Okul Öncesi Öğretmenliği lisans olan yöneticiler arasında öğrenim düzeyi Çocuk Gelişimi/Anaokulu/Okul Öncesi Öğretmenliği ön lisans olan yöneticiler lehine (U=18,000; Z=2,103; p <.05); Çocuk Gelişimi/Anaokulu/Okul Öncesi Öğretmenliği ön lisans olan yöneticiler ve öğrenim düzeyi lisans tamamlama olan yöneticiler arasında öğrenim düzeyi Çocuk Gelişimi/Anaokulu/Okul Öncesi Öğretmenliği ön lisans olan yöneticiler lehine (U=38,00; Z=2,066; p <.05); Çocuk Gelişimi/Anaokulu/Okul Öncesi Öğretmenliği ön lisans olan yöneticiler ve öğrenim düzeyi yüksek lisans olan yöneticiler arasında öğrenim düzeyi Çocuk Gelişimi/Anaokulu/Okul Öncesi Öğretmenliği ön lisans olan yöneticiler lehine (U=,000; Z=2,324; $\mathrm{p}<.05$ ); Çocuk Gelişimi/Anaokulu/Okul Öncesi Öğretmenliği ön lisans olan yöneticiler ve öğrenim düzeyi ön lisans olan yöneticiler arasında öğrenim düzeyi Çocuk Gelişimi/Anaokulu/Okul Öncesi Öğretmenliği ön lisans olan yöneticiler lehine $(U=67,500 ; Z=-2,999 ; p<.05)$ ve eğitim durumu lisans olan yöneticiler ve eğitimi durumu ön lisans olan yöneticiler arasında eğitimi durumu lisans olan yöneticiler lehine $(U=978,500 ; Z=-2,333 ; p<.05)$ gerçekleştiği belirlenmiştir. Buna göre öğrenim düzeyi Çocuk Gelişimi/Anaokulu/Okul Öncesi Öğretmenliği ön lisans olan yöneticilerin yaratıcı liderlik özellikleri öğrenim düzeyi Çocuk Gelişimi/Anaokulu/Okul Öncesi Öğretmenliği lisans, lisans tamamlama, yüksek lisans ve ön lisans olan yöneticilerin yaratıcı liderlik özelliklerinden daha fazla olduğunu ve öğrenim düzeyi lisans olan yöneticilerin yaratıcı liderlik özelliklerinin de 
öğrenim düzeyi ön lisans olan yöneticilerin yaratıcı liderlik özelliklerinden daha fazla olduğunu göstermektedir ( $\mathrm{p}>.05)$.

Tablo 6. Yöneticilerin branş değişkeni Kruskal Wallis-H testi sonucu

\begin{tabular}{|c|c|c|c|c|c|c|}
\hline $\begin{array}{l}\text { Ölçek ve Alt Ölçekler } \\
\text { Puan }\end{array}$ & Gruplar & $\mathbf{n}$ & $\begin{array}{l}\text { S1ralamalar } \\
\text { Ortalamas1 }\end{array}$ & $\mathbf{X}^{2}$ & sd & $\mathrm{p}$ \\
\hline Yaratıc1 Liderlik & $\begin{array}{l}\text { Sinıf öğretmeni } \\
\text { Okul öncesi eğitim öğretmeni } \\
\text { Branş öğretmeni } \\
\text { Toplam }\end{array}$ & $\begin{array}{l}61 \\
28 \\
64 \\
153 \\
\end{array}$ & $\begin{array}{l}72,11 \\
89,38 \\
76,24\end{array}$ & 2,945 & 2 & 0,229 \\
\hline $\begin{array}{l}\text { Değişim ve Dönüşüme } \\
\text { Odaklanma }\end{array}$ & $\begin{array}{l}\text { Sinıf öğretmeni } \\
\text { Okul öncesi eğitim öğretmeni } \\
\text { Branş öğretmeni } \\
\text { Toplam }\end{array}$ & $\begin{array}{l}62 \\
28 \\
67 \\
157\end{array}$ & $\begin{array}{l}74,55 \\
91,05 \\
78,08\end{array}$ & 2,594 & 2 & 273 \\
\hline $\begin{array}{lr}\text { Koçluk } & \text { Yapma ve } \\
\text { Birlikte } & \text { Çalışmaya } \\
\text { Odaklanma } & \end{array}$ & $\begin{array}{l}\text { Sinıf öğretmeni } \\
\text { Okul öncesi eğitim öğretmeni } \\
\text { Branş öğretmeni } \\
\text { Toplam }\end{array}$ & $\begin{array}{l}65 \\
30 \\
77 \\
172 \\
\end{array}$ & $\begin{array}{l}79,02 \\
102,78 \\
86,47\end{array}$ & 4,695 & 2 & ,096 \\
\hline $\begin{array}{ll}\text { Problem Çözme ve } \\
\text { Eleştirel } & \text { Düşünmeye } \\
\text { Odaklanma } & \end{array}$ & $\begin{array}{l}\text { Sinıf öğretmeni } \\
\text { Okul öncesi eğitim öğretmeni } \\
\text { Branş öğretmeni } \\
\text { Toplam }\end{array}$ & $\begin{array}{l}63 \\
30 \\
74 \\
167 \\
\end{array}$ & $\begin{array}{l}81,06 \\
97,57 \\
81,00\end{array}$ & 2,886 & 2 & 236 \\
\hline $\begin{array}{l}\text { Mesleki ve Kişisel } \\
\text { Gelişime Odaklanma }\end{array}$ & $\begin{array}{l}\text { Sinıf öğretmeni } \\
\text { Okul öncesi eğitim öğretmeni } \\
\text { Branş öğretmeni } \\
\text { Toplam }\end{array}$ & $\begin{array}{l}65 \\
30 \\
77 \\
172\end{array}$ & $\begin{array}{l}84,15 \\
102,22 \\
82,36\end{array}$ & 3,692 & 2 & ,158 \\
\hline
\end{tabular}

Tablo 6'da görüldüğü üzere yöneticilerin YLÖ ve alt ölçekleri için branş değişkenine göre gruplarının farklılık sınamasında Kruskal Wallis-H testinden yararlanılmıştır. Yöneticilerin "YLÖ $\left(X^{2}(2)=2,945, p>0,05\right)$ "ve "Değişim ve Dönüşüme Odaklanma $\left(X^{2}(2)=2,594, p>0,05\right)$ ", "Koçluk Yapma ve Birlikte Çalışmaya Odaklanma $\left(X^{2}(2)=4,695, p>0,05\right)$ ", "Problem Çözme ve Eleştirel Düşünceye Odaklanma $\left(X^{2}(2)=2,886, p>0,05\right)$ " ve "Mesleki ve Kişisel Gelişime Odaklanma $\left(X^{2}\right.$ $(2)=3,692, p>0,05)$ " alt ölçeklerinden elde edilen olasılık değerleri anlamlılık dereceleri 0,05'ten büyük olduğundan branş değişkeni grup sıralı ortalamaların arasındaki fark istatistiksel olarak anlamlı bulunmamaktadır. Buna göre, yöneticilerin branşları "ölçek ve alt ölçeklere ait özelliklerini etkilememektedir. 
Tablo 7. Yöneticilerin öğretmenlikteki hizmet süresi değişkeni Kruskal Wallis-H testi sonuçları

\begin{tabular}{|c|c|c|c|c|c|c|}
\hline Ölçek ve Alt Ölçekler Puan & Gruplar & $\mathbf{n}$ & SO & $\mathbf{X}^{2}$ & sd & $\mathrm{p}$ \\
\hline \multirow[t]{7}{*}{ Yaratıcı liderlik } & 1 yildan az & 2 & 124,00 & 3,397 & 5 & 0,639 \\
\hline & $1-5 \mathrm{y} 1 \mathrm{l}$ & 6 & 92,75 & & & \\
\hline & $6-10 \mathrm{y} 1 \mathrm{l}$ & 23 & 74,85 & & & \\
\hline & $11-15$ y1l & 41 & 78,26 & & & \\
\hline & $16-20$ yil & 28 & 76,46 & & & \\
\hline & 21 y1l ve üstü & 53 & 73,69 & & & \\
\hline & Toplam & 153 & & & & \\
\hline \multirow{7}{*}{$\begin{array}{l}\text { Değişim ve } \\
\text { Odaklanma }\end{array}$} & 1 yildan az & 2 & 108,25 & 1,513 & 5 & 912 \\
\hline & $1-5 \mathrm{y} 1 \mathrm{l}$ & 6 & 77,42 & & & \\
\hline & $6-10 \mathrm{y} 1 \mathrm{l}$ & 23 & 74,17 & & & \\
\hline & $11-15$ y1l & 41 & 81,73 & & & \\
\hline & $16-20$ y1l & 31 & 75,13 & & & \\
\hline & 21 y1l ve üstü & 54 & 80,30 & & & \\
\hline & Toplam & 157 & & & & \\
\hline \multirow{7}{*}{$\begin{array}{l}\text { Koçluk Yapma ve Birlikte } \\
\text { Çalışmaya Odaklanma }\end{array}$} & 1 yildan az & 2 & 154,00 & 7,088 & 5 & ,214 \\
\hline & $1-5 \mathrm{y} 1 \mathrm{l}$ & 7 & 108,07 & & & \\
\hline & $6-10$ y1l & 25 & 84,16 & & & \\
\hline & $11-15$ y1l & 42 & 92,23 & & & \\
\hline & $16-20 \mathrm{y} 1 \mathrm{l}$ & 36 & 86,43 & & & \\
\hline & 21 yıl ve üstü & 60 & 78,74 & & & \\
\hline & Toplam & 172 & & & & \\
\hline \multirow{7}{*}{$\begin{array}{l}\text { Problem Çözme ve Eleştirel } \\
\text { Düşünceye Odaklanma }\end{array}$} & 1 yildan az & 2 & 117,75 & 1,371 & 5 & 927 \\
\hline & $1-5 \mathrm{yll}$ & 7 & 90,07 & & & \\
\hline & $6-10$ y1l & 24 & 87,81 & & & \\
\hline & $11-15$ y1l & 42 & 82,15 & & & \\
\hline & $16-20 \mathrm{y} 1 \mathrm{l}$ & 32 & 82,80 & & & \\
\hline & 21 y1l ve üstü & 60 & 82,58 & & & \\
\hline & Toplam & 167 & & & & \\
\hline \multirow{7}{*}{$\begin{array}{l}\text { Mesleki ve Kişisel Gelişime } \\
\text { Odaklanma }\end{array}$} & 1 yildan az & 2 & 157,50 & 6,460 & 5 & 264 \\
\hline & $1-5 \mathrm{yll}$ & 7 & 98,93 & & & \\
\hline & $6-10$ y1l & 25 & 86,96 & & & \\
\hline & $11-15$ y1l & 42 & 86,38 & & & \\
\hline & $16-20 \mathrm{y} 1 \mathrm{l}$ & 35 & 92,73 & & & \\
\hline & 21 y1l ve üstü & 61 & 79,07 & & & \\
\hline & Toplam & 172 & & & & \\
\hline
\end{tabular}

$\overline{p>.05}$

Tablo 7'de görüldüğü üzere yöneticilerin YLÖ ve alt ölçekleri için öğretmenlikteki hizmet süresi değişkenine göre gruplarının farklılı sınaması için yapılan analize göre; "YLÖ $\left(X^{2}(5)=3,397\right.$, $p>0,05)$ ” ve “Değişim ve Dönüşüme Odaklanma $\left(X^{2}(5)=1,513, p>0,05\right)$ ”, "Koçluk Yapma ve Birlikte Çalışmaya Odaklanma $\left(X^{2}(5)=7,088, p>0,05\right)$ ", "Problem Çözme ve Eleştirel Düşünceye Odaklanma $\left(X^{2}(5)=1,371, p>0,05\right)$ " ve "Mesleki ve Kişisel Gelişime Odaklanma $\left(X^{2}(5)=6,460\right.$, $p>0,05) "$ alt ölçeklerinden elde edilen olasıllk değerleri anlamlllık dereceleri 0,05'ten büyük olduğundan yöneticilerin öğretmenlikteki hizmet süresine ait ortalama puanlarında anlamlı fark bulunmamaktadır. Bu bulgulara göre, yöneticilerin öğretmenlikteki hizmet süresi "Yaratıc1 Liderlik", "Değişim ve Dönüşüme Odaklanma”, "Koçluk Yapma ve Birlikte Çalışmaya 
Odaklanma", "Problem Çözme ve Eleştirel Düşünceye Odaklanma" ve "Mesleki ve Kişisel Gelişime Odaklanma” özelliklerini etkilememektedir.

Tablo 8. Yöneticilerin yöneticilikteki hizmet süresi değişkeni yaratıcı liderlik Kruskal Wallis-H testi sonuçları

\begin{tabular}{|c|c|c|c|c|c|c|}
\hline Ölçek ve Alt Ölçekler Puan & Gruplar & n & SO & $\mathrm{X}^{2}$ & sd & $\mathrm{p}$ \\
\hline Yaratıc1 Liderlik & $\begin{array}{l}1 \text { yildan az } \\
1-5 \text { y1l } \\
6-10 \text { yil } \\
11-15 \text { y1l } \\
16-20 \text { yil } \\
21 \text { y1l ve üstü } \\
\text { Toplam }\end{array}$ & $\begin{array}{l}15 \\
48 \\
31 \\
22 \\
26 \\
11 \\
153\end{array}$ & $\begin{array}{l}85,73 \\
69,67 \\
83,03 \\
73,25 \\
74,21 \\
94,18\end{array}$ & 4,388 & 5 & , 495 \\
\hline $\begin{array}{l}\text { Değişim ve Dönüşüme } \\
\text { Odaklanma }\end{array}$ & $\begin{array}{l}1 \text { yildan az } \\
1-5 \text { y1l } \\
6-10 \text { y1l } \\
11-15 \text { y1l } \\
16-20 \text { y1l } \\
21 \text { y1l ve üstü } \\
\text { Toplam }\end{array}$ & $\begin{array}{l}15 \\
50 \\
32 \\
22 \\
27 \\
11 \\
157 \\
\end{array}$ & $\begin{array}{l}88,10 \\
68,86 \\
82,34 \\
77,57 \\
76,63 \\
111,64\end{array}$ & 9,039 & 5 & , 108 \\
\hline $\begin{array}{l}\text { Koçluk Yapma ve Birlikte } \\
\text { Çalışmaya Odaklanma }\end{array}$ & $\begin{array}{l}1 \text { yildan az } \\
1-5 \text { y1l } \\
6-10 \text { yil } \\
11-15 \text { yil } \\
16-20 \text { yil } \\
21 \text { y1l ve üstü } \\
\text { Toplam }\end{array}$ & $\begin{array}{l}17 \\
53 \\
37 \\
23 \\
26 \\
16 \\
172 \\
\end{array}$ & $\begin{array}{l}99,32 \\
81,51 \\
91,20 \\
84,24 \\
79,00 \\
93,97\end{array}$ & 3,000 & 5 & ,700 \\
\hline $\begin{array}{l}\text { Problem Çözme ve Eleştirel } \\
\text { Düşünceye Odaklanma }\end{array}$ & $\begin{array}{l}1 \text { yildan az } \\
1-5 \text { y1l } \\
6-10 \text { y1l } \\
11-15 \text { y1l } \\
16-20 \text { y1l } \\
21 \text { y1l ve üstü } \\
\text { Toplam }\end{array}$ & $\begin{array}{l}17 \\
50 \\
35 \\
23 \\
27 \\
15 \\
167\end{array}$ & $\begin{array}{l}97,65 \\
78,81 \\
83,03 \\
78,70 \\
81,54 \\
100,67\end{array}$ & 4,084 & 5 & ,537 \\
\hline $\begin{array}{l}\text { Mesleki ve Kişisel Gelişime } \\
\text { Odaklanma }\end{array}$ & $\begin{array}{l}1 \text { yildan az } \\
1-5 \text { yil } \\
6-10 \text { y1l } \\
11-15 \text { y1l } \\
16-20 \text { y1l } \\
21 \text { y1l ve üstü } \\
\text { Toplam }\end{array}$ & $\begin{array}{l}17 \\
53 \\
36 \\
23 \\
27 \\
16 \\
172\end{array}$ & $\begin{array}{l}105,74 \\
80,58 \\
96,21 \\
74,02 \\
80,69 \\
91,59\end{array}$ & 6,685 & 5 & 245 \\
\hline
\end{tabular}

Tablo 8'de görüldüğü üzere yöneticilerin YLÖ ve alt ölçekler için yöneticilikteki hizmet süresi değişkenine göre "YLÖ $\left(X^{2}(5)=4,388, p>0,05\right)$ " ve "Değişim ve Dönüşüme Odaklanma $\left(X^{2}\right.$ $(5)=9,039, p>0,05)$ ", "Koçluk Yapma ve Birlikte Çalışmaya Odaklanma $\left(X^{2}(5)=3,000, p>0,05\right)$ ", "Problem Çözme ve Eleştirel Düşünceye Odaklanma $\left(X^{2}(5)=4,084, p>0,05\right)$ " ve "Mesleki ve Kişisel Gelişime Odaklanma $\left(X^{2}(5)=6,685, p>0,05\right)$ " alt ölçeklerinden elde edilen olasıllk değerleri anlamlılık dereceleri 0,05 'ten büyük olduğundan yöneticilikteki hizmet süresi puanları farklılaşmamaktadır. Elde edilen sonuçlara göre, yöneticilikteki hizmet süresi yöneticilerin "Yaratıc1 
Liderlik", "Değişim ve Dönüşüme Odaklanma", "Koçluk Yapma ve Birlikte Çalışmaya Odaklanma", "Problem Çözme ve Eleştirel Düşünceye Odaklanma" ve "Mesleki ve Kişisel Gelişime Odaklanma” özelliklerini etkilememektedir.

Tablo 9. Yöneticilerin çalışlan kurum türü değişkeni Kruskal Wallis-H testi sonuçları

\begin{tabular}{|c|c|c|c|c|c|c|}
\hline $\begin{array}{l}\text { Ölçek ve Alt Ölçekler } \\
\text { Puan }\end{array}$ & Gruplar & $\mathbf{n}$ & SO & $\mathbf{X}^{2}$ & sd & $\mathrm{p}$ \\
\hline \multirow[t]{8}{*}{ Yaratıcı Liderlik } & MEB Bağımsız Anaokulu & 17 & 74,74 & 12,223 & 5 & $0,032 *$ \\
\hline & Özel Anaokulu & 12 & 116,71 & & & \\
\hline & Resmi İlköğretim Okulu & 112 & 71,89 & & & \\
\hline & Özel İlköğretim Okulu & 6 & 81,75 & & & \\
\hline & Üniversitelerin Çocuk Yuvası & 2 & 99,50 & & & \\
\hline & Kız Meslek Lisesi Uygulama & 4 & 92,13 & & & \\
\hline & Anaokulu & & & & & \\
\hline & Toplam & 153 & & & & \\
\hline \multirow{8}{*}{$\begin{array}{l}\text { Değişim ve Dönüşüme } \\
\text { Odaklanma }\end{array}$} & MEB Bağımsız Anaokulu & 17 & 77,85 & 13,474 & 5 & ,019* \\
\hline & Özel Anaokulu & 14 & 112,75 & & & \\
\hline & Resmi İlköğretim Okulu & 114 & 73,14 & & & \\
\hline & Özel İlköğretim Okulu & 6 & 92,08 & & & \\
\hline & Üniversitelerin çocuk Yuvası & 2 & 137,25 & & & \\
\hline & Kız Meslek Lisesi Uygulama & 4 & 84,13 & & & \\
\hline & Anaokulu & & & & & \\
\hline & Toplam & 157 & & & & \\
\hline \multirow{8}{*}{$\begin{array}{l}\text { Koçluk Yapma ve } \\
\text { Birlikte Çalışmaya } \\
\text { Odaklanma }\end{array}$} & MEB Bağımsız Anaokulu & 21 & 88,45 & 9,908 & 5 & ,078 \\
\hline & Özel Anaokulu & 15 & 120,17 & & & \\
\hline & Resmi İlköğretim Okulu & 124 & 80,73 & & & \\
\hline & Özel İlköğretim Okulu & 6 & 97,42 & & & \\
\hline & Üniversitelerin çocuk Yuvası & 2 & 88,25 & & & \\
\hline & Kız Meslek Lisesi Uygulama & 4 & 111,63 & & & \\
\hline & Anaokulu & & & & & \\
\hline & Toplam & 172 & & & & \\
\hline Problem Çözme ve & MEB Bağımsız Anaokulu & 20 & 87,35 & 8,309 & 5 & ,140 \\
\hline Eleştirel Düşünceye & Özel Anaokulu & 13 & 115,73 & & & \\
\hline \multirow[t]{6}{*}{ Odaklanma } & Resmi İlköğretim Okulu & 122 & 79,02 & & & \\
\hline & Özel İlköğretim Okulu & 6 & 84,25 & & & \\
\hline & Üniversitelerin çocuk Yuvası & 2 & 93,50 & & & \\
\hline & Kız Meslek Lisesi Uygulama & 4 & 110,75 & & & \\
\hline & Anaokulu & & & & & \\
\hline & Toplam & 167 & & & & \\
\hline Mesleki ve Kişisel & MEB Bağımsız Anaokulu & 21 & 84,40 & 11,441 & 5 &, $043 *$ \\
\hline \multirow[t]{7}{*}{ Gelişime Odaklanma } & Özel Anaokulu & 15 & 125,47 & & & \\
\hline & Resmi İlköğretim Okulu & 124 & 81,58 & & & \\
\hline & Özel İlköğretim Okulu & 6 & 82,92 & & & \\
\hline & Üniversitelerin Çocuk Yuvası & 2 & 85,00 & & & \\
\hline & Kız Meslek Lisesi Uygulama & 4 & 110,00 & & & \\
\hline & Anaokulu & & & & & \\
\hline & Toplam & 172 & & & & \\
\hline
\end{tabular}

Tablo 9'da görüldüğü üzere yöneticilerin çalışılan kurum türü değişkenine göre "YLÖ ile $\left(X^{2}\right.$ $(5)=12,223, p<0,05)$ ”, "Değişim ve Dönüşüme Odaklanma $\left(X^{2}(5)=13,474, p<0,05\right)$ " ve "Mesleki ve Kişisel Gelişime Odaklanma $\left(X^{2}(5)=11,441, p<0,05\right)$ " alt ölçeklerine ait olasılık değerleri anlamlılık derecesi 0,05 ten küçük olduğundan çalış1lan kurum türü puanları istatistiksel olarak 
anlamlı bulunurken, "Koçluk Yapma ve Birlikte Çalışmaya Odaklanma $\left(X^{2}(5)=9,908, p>0,05\right)$ " ve "Problem Çözme ve Eleştirel Düşünceye Odaklanma $\left(X^{2}(5)=8,309, p>0,05\right)$ " alt ölçeklerine ait olasılık değerleri anlamlılık derecesi 0,05 'ten büyük olduğundan çalışılan kurum türü puanlarındaki fark istatistiksel olarak anlamlı bulunmamıştır. YLÖ ile ilgili olarak istatistiksel farklıllğa sebep olan özel anaokulunda çalışan yöneticilerin oluşturduğu gruba ait sıralı ortalama puanlarının diğer grupların puanlarından anlamlı derecede fazla olduğu, bunu sırasıyla üniversitelerin çocuk yuvası, kız meslek lisesi uygulama anaokulu, özel ilköğretim okulu, resmi ilköğretim okulu ve MEB bağımsız anaokulunda çalışan yöneticilerin izlediği görülmektedir. "Değişim ve Dönüşüme Odaklanma” alt ölçeğinde istatistiksel farklıllğa sebep olan grup üniversitelerin çocuk yuvasında çalışan yöneticilerin oluşturduğu grubun puanları diğer grupların puanlarından anlamlı derecede fazladır. Sırasıyla bunu özel anaokulu, özel ilköğretim okulu, kız meslek lisesi uygulama anaokulu, MEB bağımsız anaokulu ve resmi ilköğretim okulunda çalışmakta olan yöneticilerin izlediği görülmektedir. "Mesleki ve Kişisel Gelişime Odaklanma” alt ölçeğinde ise istatistiksel farklllı̆̆a sebep olan özel anaokulunda çalışan yöneticilerin oluşturduğu grubun sıralı ortalama puanlarının diğer gruplardan anlamlı derecede fazla olduğu, bunu sırasıyla, kız meslek lisesi uygulama anaokulu, üniversitelerin çocuk yuvası, MEB bağımsız anaokulu, özel ilköğretim okulu ve resmi ilköğretim okulunda çalısan yöneticilerin izlediği görülmektedir. Araştırmaya katılan yöneticilerin çalışmakta oldukları kurum türü ölçeğin diğer alt ölçekleri olan "Koçluk Yapma ve Birlikte Çalışmaya Odaklanma" ve "Problem Çözme ve Eleştirel Düşünceye Odaklanma" özelliklerini etkilememektedir.

Bu işlemin ardından, "Yaratıcı Liderlik" Özellikleri ve "Mesleki ve Kişisel Gelişime Odaklanma" "Değişim ve Dönüşüme Odaklanma” alt ölçekleri için belirlenen anlamlı farklılığın kaynaklandığı grupları saptamak için Mann Whitney U Testi uygulanarak anlamlı fark bulunan gruplara ait sonuçlar Tablo 10.'da sunulmuştur.

Tablo 10. Yöneticilerin çalışlan kurum türü değişkeni Mann Whitney U testi sonuçları

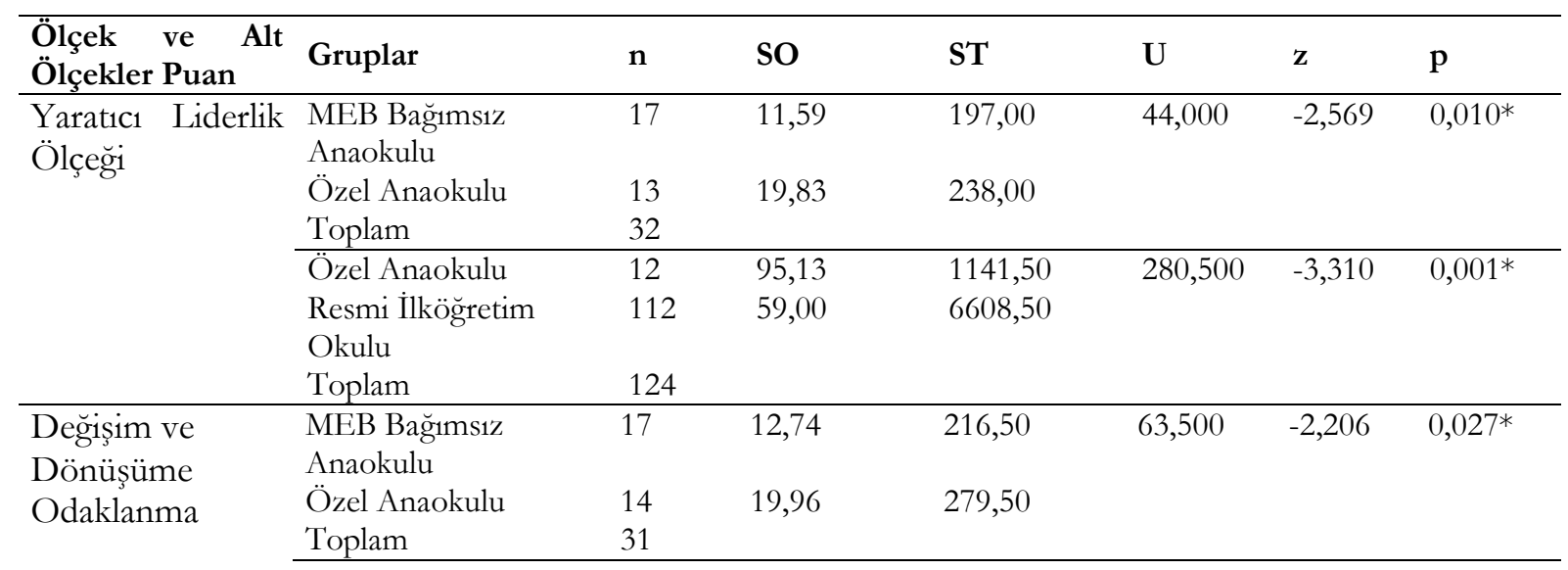




\begin{tabular}{|c|c|c|c|c|c|c|c|}
\hline $\begin{array}{l}\text { Ölçek ve Alt } \\
\text { Ölçekler Puan }\end{array}$ & Gruplar & $\mathbf{n}$ & SO & ST & $\mathbf{U}$ & $\mathbf{z}$ & $\mathrm{p}$ \\
\hline & MEB Bağımsız & 17 & 9,12 & 155,00 & 2,000 & $-1,996$ & $0,046^{*}$ \\
\hline & Anaokulu & & & & & & \\
\hline & Üniversite Çocuk & 2 & 17,50 & 35,00 & & & \\
\hline & Yuvas1 & & & & & & \\
\hline & Toplam & 19 & & & & & \\
\hline & Özel Anaokulu & 14 & 93,18 & 1304,50 & 396,500 & $-3,068$ & $0,002^{*}$ \\
\hline & Resmi İlköğretim & 114 & 60,98 & 6951,50 & & & \\
\hline & Okulu & & & & & & \\
\hline & Toplam & 128 & & & & & \\
\hline & $\begin{array}{l}\text { Resmi İlköğretim } \\
\text { Okulu }\end{array}$ & 114 & 57,68 & 6576,00 & 21,000 & $-1,974$ & $0,048^{*}$ \\
\hline & Üniversite Cocuk & 2 & 105,00 & 210,00 & & & \\
\hline & Yuvas1 & & & & & & \\
\hline & Toplam & 116 & & & & & \\
\hline \multirow{7}{*}{$\begin{array}{l}\text { Mesleki ve Kişisel } \\
\text { Gelişime }\end{array}$} & MEB Bağımsız & 21 & 14,90 & 313,00 & 82,000 & $-2,452$ & $0,014^{*}$ \\
\hline & Anaokulu & & & & & & \\
\hline & Özel Anaokulu & 15 & 23,53 & 353,00 & & & \\
\hline & Toplam & 36 & & & & & \\
\hline & Özel Anaokulu & 15 & 101,93 & 1529,00 & 451,000 & $-3,263$ & $0,001^{*}$ \\
\hline & Resmi İlköğretim & 124 & 66,14 & 8201,00 & & & \\
\hline & $\begin{array}{l}\text { Okulu } \\
\text { Toplam }\end{array}$ & 139 & & & & & \\
\hline
\end{tabular}

Tablo 10'da yapılan analizler sonucunda YLÖ için farklılığın, özel anaokulunda çalısmakta olan yöneticilerle MEB Bağımsız Anaokulunda çalışmakta olan yöneticiler arasında özel anaokulunda çalışmakta olan yöneticilerin lehinedir $(\mathrm{U}=44,000 ; \mathrm{Z}=-2,569 ; \mathrm{p}<.05)$. Özel anaokullarında çalışmakta olan yöneticilerle resmi ilköğretim okullarında çalışmakta olan yöneticiler arasında ise özel anaokulunda çalışmakta olan yöneticilerin lehine (U=280,500; Z=-3,310; p <.05) olduğu görülmektedir. Buradan elde edilen sonuçlar; özel anaokulunda çalışmakta olan yöneticilerin yaratıcı liderlik özelliklerinin MEB bağımsız anaokulunda çalışmakta olan yöneticiler ve resmi ilköğretim okulunda çalısmakta olan yöneticilerin "Yaratıcı Liderlik" özelliklerinden daha fazla olduğunu göstermektedir ( $p>.05)$.

"Değişim ve Dönüşüme Odaklanma” alt ölçeği ile ilgili olarak yapılan analizler sonucunda farklılığın, özel anaokulunda çalışan yöneticilerle MEB bağımsız anaokulunda çalışan yöneticiler arasında özel anaokulunda çalışan yöneticilerin lehinedir ( $U=63,500 ; \mathrm{Z}=-2,206 ; \mathrm{p}<.05)$. Özel anaokullarında çalışan yöneticilerle resmi ilköğretim okullarında çalışan yöneticiler arasında ise özel anaokulunda çalışan yöneticilerin lehine ( $U=396,500 ; Z=-3,068 ; p<.05)$; üniversitelere ait çocuk yuvasında çalışmakta olan yöneticilerle MEB bağımsız anaokulunda çalışan yöneticiler arasında üniversite çocuk yuvasında çalışan yöneticiler lehine $(\mathrm{U}=2,000 ; \mathrm{Z}=-1,996 ; \mathrm{p}<.05)$ ve üniversitelere ait çocuk yuvasında çalışan yöneticilerle resmi ilköğretim okulunda çalışan yöneticiler arasında üniversite çocuk yuvasında çalş̧an yöneticilerin lehine ( $U=21,000 ; Z=-1,974 ; p \quad<.05)$ gerçekleştiği belirlenmiştir. Buna göre özel anaokulunda çalışan yöneticilerin "Değişim ve Dönüşüme 
Odaklanma” özelliklerinin resmi ilköğretim okulunda çalışan yöneticilerin ve MEB bağımsız anaokulunda çalışan yöneticilerden daha fazla olduğu ve üniversite çocuk yuvasında çalışan yöneticilerin "Değissim ve Dönüşüme Odaklanma” özelliklerinin ise resmi ilköğretim okulunda çalışan yöneticiler ve MEB Bağımsız anaokulunda çalışan yöneticilerden daha fazla olduğu görülmektedir. Bir başka deyişle özel anaokulunda çalışan yöneticilerin ve üniversite çocuk yuvasında çalışan yöneticilerin “Değişim ve Dönüşüme Odaklanma” özellikleri resmi ilköğretim okulunda çalışan yöneticiler ve MEB bağımsız anaokulunda çalışan yöneticilerden daha fazladır $(\mathrm{p}>.05)$.

"Mesleki ve Kişisel Gelişime Odaklanma” alt ölçeği ile ilgili yapılan analizler sonucunda farklılığın, Özel anaokulu çalışan yöneticilerle MEB bağımsız anaokulunda çalışan yöneticiler arasında özel anaokulu çalışan yöneticilerin lehine $(U=82,000 ; Z=-2,452 ; p<.05)$ ve özel anaokulunda çalışan yöneticilerle resmi ilköğretim okulunda çalışan yöneticiler arasında özel anaokullarında çalışan yöneticilerin lehine $(U=451,000 ; Z=-3,263 ; \mathrm{p}<.05)$ gerçekleştiği belirlenmiştir. Bu bulgulara göre özel anaokullarında çalışmakta olan yöneticilerin mesleki ve kişisel gelişime odaklanma özelliklerinin resmi ilköğretim okullarında çalışmakta olan yöneticilerin ve MEB Bağımsız anaokulunda çalışmakta olan yöneticilerin "Mesleki ve Kişisel Gelişime Odaklanma” özelliklerden daha fazla olduğunu göstermektedir. Bir başka deyişle Özel Anaokulunda çalışmakta olan yöneticilerin mesleki ve kişisel gelişime odaklanma özelliklerinin MEB Bağımsız anaokulunda çalışmakta olan yöneticilerin ve Resmi İlköğretim Okulunda çalışmakta olan yöneticilerin "Mesleki ve Kişisel Gelişime Odaklanma” özelliklerden daha fazla olduğunu göstermektedir ( $p>$.05).

\section{SONUÇ ve TARTIŞMA}

Yöneticilerin yaratıcı liderlik özelliklerinin belirlenmesi ile ilgili ulaşılan yargıda yöneticilerin yaratıcı liderlik özellikleri ölçek ve alt ölçeklerde orta düzeyin üzerinde olduğu ortaya çıkmıştır. Alanda yapılmış olan farklı araştırmalarda örneğin; Turan ve Ebiçlioğlu (2002) tarafindan yapılan araştırmada da okul müdürlerinin etkili liderlik nitelikleri düzeylerinin de ortanın üzerinde olduğunu görülmüştür. Bu bulgu da yapılan araştırmada elde edilen bulguyu destekler niteliktedir. Taş ve Çetiner (2011)'in araştırmasına göre ise de okul müdürleri dönüşümcü liderlik davranışlarını yüksek düzeyde gerçekleşmemektedir. Liderlik stilleri ve bireylerin yaratıcılık özelliklerinin incelendiği araştırmalardan bazılarında; Gündüz ve Doğan (2009) tarafindan okul yöneticilerinin yaratıcılık düzeyleri ile liderlik stillerini belirlemeye yönelik olarak yapılan araştırmada ise yöneticilerinin liderlik stilleri ile yaratıcılık düzeyleri arasında anlamlı bir fark olmadığı görülmüştür (Can, 2005; Urbanski ve Nickolaou, 2006; akt. Can, 2006). Bu yargılardan bazıları araştırmada elde edilen 
yargılardan farklılık göstermektedir. Bu durumun araştırma sonucuyla örtüşmemesi diğer araştırmaların konuya farklı yaklaşımlarından ya da veri toplama araçlarının farklı olmasından kaynaklanıyor olabilir. Yapılan araştırmadan elde edilen yargı araştırmaya katılan yöneticilerin yaratıcı liderlik özellikleri ile ilgili algılarının bu yönde olduğunu biçimde yorumlanmıştır. Ayrıca yaratıcı problem çözme ile ilgili araştırmalarda da, grupların yaratıı performanslarını liderlerin aracıllğı ile arttığ1 belirtilmektedir. Güçlendirici liderlik yaklaşımı çalışanlarının liderliklerini ve yaratıcılıklarını desteklemektedir. Ayrıca araştırmalar, dönüşümcü liderlik ve çalışanların yüksek derecedeki yaratıcıllı̆̆ arasında ilişki olduğunu göstermektedir (Jung, vd., 2001; Sosik, vd., 1998; akt. Houghton ve Yoho 2005). Alanyazında ayrıca lider de bulunması gereken kişisel özelliklerden birisinin de yaratıcılık olduğuna dikkat çekilerek (Daft, 1991: 373; akt. Bakan ve Büyükbeşe, 2010) yöneticilerden; öğrenim süreçlerini başlatan, astların yeteneklerini, yaratıcılıklarını optimal düzeyde geliştirmesi ve örgütün amaçlarının gerçekleşmesine katkıda bulunması gereken kişiler olmalanı da beklenmektedir (Hesapçıŏlu, 1998, s.102; akt. Gümüşeli, 2001). Yukarıda yer alan açıklamalarda liderlik özelliklerinin yaratıcılık ve çalışan performasında etkili olduğu görülmektedir. Yapılan alan yazın taramasında da yaratıcı liderlik özelliklerine sahip liderlerin çalışanlarının performansları ve yaratıcılık özelliklerini olumlu yönde etkiledikleri de yer almaktadır. Yaratcı liderlik özelliklerine sahip liderlieğin kurumlarına ve çalışanlarına sağladığı kazanımlar dikkate alındığında yapılan araştırmanın yaratıcı liderlik kavramının önemine dikkat çekerek alana katkı sağlayacağı düşünülmektedir.

Yöneticilerin YLÖ puanları ile "Mesleki ve Kişisel Gelişime Odaklanma" ve "Değişim ve Dönüşüme Odaklanma” puanlarında cinsiyet değişkenine göre kadın yöneticilerin lehine anlamlı bir farklılıklar bulunmaktadır. Buna göre kadın yöneticilerin, erkek yöneticilere göre yaratıcı liderlik düzeyleri, "Mesleki ve Kişisel Gelişime Odaklanma" ve "Değişim ve Dönüşüme Odaklanma" düzeyleri daha yüksektir. Alanda yapılmış olan farklı araştırmalar da ulaşılan bazı yargıllarda ise erkek yöneticilerin liderlik özelliklerinin daha yüksek düzeyde olduğuna işaret eden yapılan araştırmanın bulguları ile örtüşmeyen çalışmalar da bulunmaktadır. Buna göre elde edilen bulgular alanyazındaki bazı bulgular ile tutarlı iken bazıları ile de çelişki göstermektedir. Titrek, Bayrakçı ve Zafer (2009)'in araştırma bulgularına göre de okul yöneticilerinin cinsiyet değişkenine göre anlamlı olarak farklılaştı̆̆1 saptanmıştır. Yöneticilerin cinsiyet değişkenine göre YLÖ’nün diğer alt ölçeklerine ait puanlarda anlamlı farklılık bulunmaktadır. Bu bulgu, kadın ve erkek yöneticilerin cinsiyetlerinin "Problem Çözme ve Eleştirel Düşünmeye Odaklanma” ve "Koçluk Yapma ve Birlikte Çalışmaya Odaklanma" düzeylerini etkilemediğini göstermiştir. Ulaşılan bu yargiya benzer olarak alanda yapılmış olan farklı araştırmalar da, kadın yöneticilerin ve erkek yöneticilerin liderlik özelliklerinin farklılaşmadığına işaret etmektedirler. Örneğin, Turan ve Ebiçlioğlu (2002) tarafindan kadın ve 
erkek okul yöneticilerinin liderlik niteliklerini saptamak için yapılan araştırmada ve Durukan, Can, Göktaş ve Arıkan (2006) tarafından yapılan araştırma bulgularına göre "Yapıyı Kurma Boyutundaki" liderlik davranışlarında cinsiyetlere göre anlamlı farklılık bulunmamıştır. Cinsiyetin dönüşümcü liderlik ve duygusal zekâ ile olan ilişkisini inceleyen Mandell ve Pherwani (2003)'nin elde ettikleri bulgularda ise kadın ve erkek yöneticilerin dönüşümcü liderlik puanları arasında da farklılık bulunmamıştır. Can ve Pepe (2003)'nin bulguları da bu bulgularla benzerlik göstermektedir. Buradan hareketle araştırmanın bulgularının alanyazındaki bulgulardan bazılarıyla tutarlı iken bazılarıyla da çelişmekte olduğu söylenebilir. Yöneticilik ve liderlik kavramlarında cinsiyet önemli belirleyicilerden birisi gibi alg1lanarak toplumda yöneticilik ve liderlik rolünü daha çok erkekler oynamaktadır (Çelebi, 2009). Ancak Erçetin (2000)'e göre liderlikte kadınlar da erkekler kadar başarılı olmaktadırlar. Bu ifade yapılan araştırmada elde edilen yargıyı desteklemektedir. Erkek ve kadınlara atfedilen toplumsal cinsiyet rol kalıplarında erkeklerin iş hayatında kadınlara göre yöneticilik rolleri ön plan çıkarılmaktadır. Güç dengeleri ve sosyo-kültürel değerlerin kadınların liderlik durumlarına etki eden etmenlerden olduğu ifade edilmektedir (Madden, 2005;akt. Çelebi, 2009). Bu bağlamda kadın yöneticilerin yaratıcı liderlik özelliklerinin erkek yöneticilerden daha fazla olmasının nedenini kadın yöneticilere atfedilen liderlik özellikleri ile yaratıcı liderlik özelliklerin örtüşüyor olmasından kaynaklanabileceği biçimde yorumlanmıştır.

Yöneticilerin yaş değişkenine göre YLÖ ve alt ölçeklere ait puanlar anlamlı bir farkl1lık göstermemektedir. Elde edilen bulguya göre, yöneticilerin yaşları ölçek ve alt ölçekler için yaratıcı liderlik özelliklerinde etkili değildir. Alanda yapılan farklı araştırmalar da ulaşılan bu yargıya benzer olarak, yaş değişkenine göre yöneticilerin liderlik özeliklerinin farklılaşmadığına işaret etmektedirler. Örneğin, Can (2008), Bennis (2003), Açıkalın (2000) ve Korkut (1992) yaptığı çalışmalarda da yaşın liderlik özellikleri üzerinde etkili olmadığı saptanmıştır (Doğan, 2005;akt. Vural, 2008). Bu araştırmalardan elde edilen bulgular da, yapılan araştırmanın sonuçlarını desteklemektedir. Yöneticilerin liderlik özelliklerinin saptanmasında yaşın önemli bir kriter olmadığı ve yaş değişkeninin yöneticilerin yaratıcı liderlik özellikleri üzerinde herhangi bir farklıllğg neden olmadığ1 saptanmıştır. Yaş değişkeni özellikler kuramında yer almaktadır. Özellikler kuramının liderlik kavramını açıklamada yetersiz kalması nedeniyle yeni yaklaşımlar geliştirilmeye devam edilmektedir. Araştırmadan elde edilen yargı yaratıcı liderlik yaklaşımının yeni liderlik yaklaşımları arasında yer almasından kaynaklanıyor olabileceği biçiminde yorumlanabilir.

Yöneticilerin YLÖ puanlarında öğrenim düzeylerine göre anlamlı farklılık bulunmaktadır. İstatistiksel olarak anlamlı farklılığa neden olan Çocuk Gelişimi Bölümü Ön lisans öğrenim düzeyi olan yöneticilerin oluşturduğu gruba ait puanlar diğer gruplardan fazladır. Bu gruba ait puanların 
sırasıyla öğrenim düzeyleri Çocuk Gelişimi/Anaokulu/Okul Öncesi Öğretmenliği lisans, lisans tamamlama, yüksek lisans ve ön lisans olan yöneticilerden daha fazla olduğu görülmektedir. Ayrıca lisans öğrenim düzeyine sahip olan yöneticilerin yaratıcı liderlik özelliklerinin de ön lisans mezunu olan yöneticilerin yaratıcı liderlik özelliklerinden daha fazla olduğu da görülmektedir. Diğer grupların arasında istatistiksel olarak anlamlı farklılık bulunmamıştır. Resmi okul ve özel okul yöneticilerinin alt ölçeklere ait puanları ise öğrenim düzeyi değişkeni göre farklılaşmamaktadır. Alanda yapılan farklı çalışmalarda elde edilen bu yargıya benzer olarak, yöneticilerin liderlik özelliklerinin öğrenim düzeylerine göre anlamlı olarak farklılığa neden olmadığını gösteren bulgular elde edilmiştir. Örneğin; araştırma elde edilen bu bulgu Şahin (2005), Çobanoğlu (2003), Bayraker (2003), Şahin (2006) ve Eraslan (2003)'ın araştırma bulgularıyla da örtüşmektedir (akt. Tahaoğlu ve Gedikoğlu, 2009). Ancak yapılan araştırmada YLÖ puanlarından elde edilen yargıya göre yöneticilerin öğrenim düzeyleri puanlarında anlamlı farklılık bulunmaktadır. Bu farklılığın eğitim durumu Çocuk Gelişimi/Anaokulu/Okul Öncesi Öğretmenliği ön lisans olan yöneticilerin lehine çıkmış olması, araştırmanın şehir merkezinde yapılmış olmasından, yöneticilerin genellikle yaşça büyük olmalarından ve resmi ve özel ilköğretim okullarında çalışmakta olan yöneticilerin yöneticilik deneyimlerinin fazla olmasından kaynaklanıyor olabileceği biçimde yorumlanmıştır.

Yöneticilerin YLÖ ve alt ölçeklere ait puanlarında branş değişkenine göre farklılaşmamaktadır. Buna göre, yöneticilerin branşları yaratıcı liderlik özelliklerini etkilememektedir. Örneğin, Vural (2008), Çelik ve Eryılmaz (2006) ve Cemaloğlu (2007) tarafindan yapılan araştırmalarda da branşlara göre anlamlı fark bulunamazken Çetiner (2008) tarafından yapılan araştırmada ise branş değişkenine göre anlamlı fark bulmuştur (akt. Taş ve Çetiner, 2011). Bu yargılardan bazıları araştırmanın yargıları ile örtüşmemektedir. Belirtilen araştırmalarda kullanılan ölçme araçlarının ve örneklemlerin farklı olmasından dolayı yargıların farklılık göstermiş olduğu ifade edilebilir.

Yöneticilerin YLÖ ve alt ölçeklere ait puanlarını yöneticilikteki hizmet süresi ve öğretmenlikteki hizmet süresi değişkenlerine göre farklılaşmamaktadır. $\mathrm{Bu}$ bulguya göre, yöneticilerin öğretmenlikteki ve yöneticilikteki hizmet süresi yaratıcı liderlik özelliklerini etkilememektedir. Örneğin, Aksu, Şahin Fırat ve Şahin (2003), Açıkalın (2002) ve Şahin (2005) ve Altınkurt (2007)'un araştırma sonuçlarında da yöneticilerin hizmet sürelerine göre anlamlı bir fark saptanmamıştır. Yapılan araştırmadan elde edilen bulgulara göre yöneticilerin yaratıcı liderlik özelliklerinin saptanmasında hizmet süresinin önemli bir kriter olmadığ1 görülmüştür. Yöneticilerin hizmet sürelerine göre yaratıcı liderlik özelliklerinin değişmemesi; yöneticilik yapabilmek belli bir hizmet süresine sahip olma zorunluluğu olması ve Milli Eğitim Bakanlığının yöneticilere yönelik zorunlu hizmet içi eğitim ve seminerler düzenliyor olmasından kaynaklanabileceği biçiminde yorumlanabilir. 
Yöneticilerin "YLÖ” ile "Mesleki ve Kişisel Gelişime Odaklanma" ve "Değişim ve Dönüşüme Odaklanma" alt ölçeği puanları çalışılmakta olan kurum türüne göre farklılaşırken, diğer alt ölçeklere ait puanlarının farklılaşmadığı görülmektedir. Bu bulgulara göre; özel anaokullarında çalışmakta olan yöneticilerin "Yaratıcı Liderlik Özellikleri", "Mesleki ve Kişisel Gelişime Odaklanma" ve "Değişim ve Dönüşüme Odaklanma" özellikleri MEB bağımsız anaokulunda ve resmi ilköğretim okulunda çalışan yöneticilerin yaratıcı liderlik özelliklerden daha fazla olduğu görülmektedir. Ayrıca üniversite çocuk yuvasında çalışan yöneticilerin "Değişim ve Dönüşüme Odaklanma” Özelliklerinin resmi ilköğretim okulunda çalışan yöneticiler ve MEB bağımsız anaokulunda çalışan yöneticilerin değişim ve dönüşüme odaklanma özelliklerden daha fazla olduğu da görülmektedir. Alanda yapılan farklı araştırmalar da ulaşılan bu yargıyı destekler biçimde yöneticilerin liderlik özelliklerinin çalışllan kurum türünün anlamlı farklılı̆̆a neden olduğunu gösteren araştırmalarda vardır. Örneğin, Titrek ve diğerleri (2009) okul türü ile ilgili Hacıfazlığlu ve diğerleri (2010)'nin araştırmalarında ise resmi okul ve özel okul yöneticileri arasında bir farklılık saptamışlardır. Diğer alt ölçeklerde kurum türü açısından anlamlı farklılık bulunmaması "Problem Çözme ve Eleştirel Düşünceye Odaklanma” ve “Koçluk Yapma ve Birlikte Çalışmaya Odaklanma” özelliklerini yöneticilerin çalısmakta oldukları kurum türünün etkilemediği biçiminde yorumlanmıştır. Alanda yapılan çeşitli araştırmalarda da ulaşılan bu yargıyı destekler nitelikte çalışılan kurum türünün yöneticilerin liderlik özelliklerinde farklılaşmaya neden olmadığını göstermektedir. Örneğin, Tengilimlioğlu (2005), Çelik (2006) ve Can (2003) araştırmalarında da kurum türü değişkenine göre anlamlı bir fark saptamamıştır (Hacıfazlığlu, Karadeniz ve Dalgıç, 2010). Farklılaşma politikası ve piyasa rekabeti, özel okul yöneticilerini teknolojik yeterliliklerini geliştirmeye zorlamaktadır (Hacıfazlıoğlu, vd., 2010). Yaratıcılık ve yenilik kurumların gelişmesinde ve güçlü kalmasında dikkat çeken önemli yeterliklerdendir (Amabile, vd., 1988; Kanter, 1983; Tushman ve O'Reilly, 1997; Utterback, 1994; Woodman vd., 1993; akt. Diliello ve Houghton, 2006). Yapılan araştırmada YLÖ ile "Mesleki ve Kişisel Gelişime Odaklanma" ve "Değişim ve Dönüşüme Odaklanma” özelliklerinde çalışlan kurum türüne göre özel anaokullarının lehine anlamlı farklılık bulunmuş olması özel anaokullarının yenilik ve farklılık yaratmak için kendi gelişimlerini resmi okullardan daha fazla önemsiyor oldukları biçimde yorumlanmış ve bu konuda özel okullarının aralarında yaşamış oldukları pazar rekabetinin de etkili olabileceği düşünülmektedir.

\section{ÖNERİLER}

Yapılan araştırmada resmi ve özel anaokulları ve bünyesinde okul öncesi eğitim sınıfı bulunan kurumlarda çalışmakta olan yöneticilerin yaratıcı liderlik özelliklerinin cinsiyet, eğitim durumu, yaş, çalışılan kurum türü, öğretmenlikteki hizmet süresi ve yöneticilikteki hizmet süreleri açısından 
farklılaşıp farklılaşmadığının saptanması amaçlanmıştır. Araştırmadan elde edilen yargılara göre uygulamacılara yönelik geliştirilen öneriler; araştırmadan elde edilen ilk yargıya göre yöneticilerin yaratıcı liderlik özelliklerinde genel olarak kadın yöneticilerin lehine anlamlı bir farklılık bulunmaktadır. Bu bağlamda erkek yöneticilerin de yaratıcı liderlik özelliklerinin geliştirilmesine yönelik hizmet içi eğitim programlarının hazırlanması öneri olarak belirtilebilir. Araştırmada yöneticilerin yaratıcı liderlik ölçeği puanlarının genel olarak özel anaokulunda çalışmakta olan yöneticilerin lehine anlamlı bir farklılık gösterdiği de belirlenmiştir. Bu bağlamda resmi okullarda çalışmakta olan yöneticilerin de yaratıcı liderlik özelliklerinin geliştirilmesine yönelik hizmet içi eğitim programlarının hazırlanması da öneri olarak belirtilebilir. Ayrıca araştırmada yöneticilerin YLÖ puanlarında öğrenim düzeylerine göre de anlamlı farklılık bulunmaktadır. Bu yargıdan hareketle öğrenim düzeylerine göre yaratıcı liderlik özelliklerinin geliştirilmesi gereken gruplara yönelik olarak da hizmet içi eğitim programlarının hazırlanması biçiminde sıralanabilir. Araştırmanın amacından hareketle araştırmacılara yönelik olarak ise; yaratıcı liderlik özelliklerinin farklı eğitim kademelerinde çalışmakta olan yöneticileri kapsayacak biçimde nicel ve nitel yöntemlerin birlikte kullanıldığı araştırmaların yapılması, farklı eğitim kademelerinde çalışmakta olan yöneticilerin yaratıcı liderlik özelliklerinin öğrencilerinin başarısına olan etkilerinin incelenmesine yönelik araştırmaların yapılması da birer öneri olarak sunulabilir.

\section{KAYNAKÇA}

Açıalın, A. (2000). İlkögretim okulu yöneticilerinin dönüşümcü liderlike özellikleri ile empati becerileri arasındaki ilişkei. Yayımlanmamış Yüksek Lisans Tezi, Gazi Üniversitesi, Eğitim Bilimleri Enstitüsü, Ankara.

Agbor, E. (2008). Creativity and innovation: the leadership dynamics. Journal of Strategic Leadership, $1(1), 39-45$.

Aksu, A., Şahin Fırat, N. \& Şahin, İ. (2003). İlköğretim okulu müdürlerinin kültürel liderlik davranışlar1. Kuram ve Uygulamada Eğitim Yönetimi, 36, 490-507.

Altınkurt, Y. (2007). Eğitim örgütlerinde stratejik liderlik ve okul müdürlerinin stratejik liderlik uygulamalar. Yayınlanmamış Doktora Tezi, Anadolu Üniversitesi, Eğitim Bilimleri Enstitüsü, Eskişehir.

Bakan, İ. \& Büyükbeşe, T. (2010). Liderlik “türleri” ve "güç kaynakları"na ilişkin mevcut-gelecek durum karşılaştırması: eğitim kurumu yöneticilerinin algılarına dayalı bir alan araştırması. KMÜ Sosyal ve Ekonomike Arastrmalar Dergisi 12(19), 73-84.

Can, N. (2006). Öğretmen liderliği ve engelleri. Sosyal Bilimler Arastırmalar Dergisi. 2, 137-161.

Can, T. (2008). İlköğretim okulları yöneticilerinin teknolojik liderlik yeterlilikleri: Ankara ili Etimesgut ilçesi örneği. 8th International Educational Technology Conference. Eskişehir, 06-09 May1s.

Cemaloğlu, N. (2007). Okul yöneticilerinin liderlik stilleri ile yıldırma arasındaki ilişki. Hacettepe Üniversitesi Eğitim Fakültesi Dergisi (H. U. Journal of Education) 33, 77-87.

Cohen, L., Manion, L., \& Morrison, K. (2007). Research methods in education. New York: Routledge. 
Creswell, J. W. (2012). Educational research: planning, conducting, and evaluating quantitative and qualitative research (4. Edition ). USA: Pearson Education Inc.

Çelebi, S. (2009). Özel ve kamu ilkögretim okullarnnda görev yapan müdürlerin göstermis olduklarn ögretim liderliği davramıslarnna iliskin ögretmenlerin ve müdür yardımcllarmın algılar. Yayınlanmamıș Yüksek Lisans Tezi, Mersin Üniversitesi, Sosyal Bilimler Enstitüsü, Mersin.

Çelik, B. (2006). Özel ve resmi ilköğretim okullarnnda çalısan eğitim yöneticilerinin algzlanan liderlik özelliklerinin incelenmesi. Yayınlanmamış Yüksek Lisans Tezi, Yeditepe Üniversitesi, Sosyal Bilimler Enstitüsü, İstanbul.

Çelik, S. \& Eryılmaz, F. (2006). Öğretmen algılarına göre endüstri meslek lisesi müdürlerinin dönüşümcü liderlik düzeyleri (Ankara ili örneği). Politeknik Dergisi, 9(4), 211-224.

Diliello, T.C. \& Houghton, J.D. (2006). Maximizing organizational leadership capacity for the future toward a model of self-leadership, innovation and creativity. Journal of Managerial Psychology, 21(4). 319-337.

Durukan, E., Can, S., Göktaş, Z. \& Arıkan, A. N. (2006). Selçuk üniversitesi beden eğitimi ve spor yüksekokulu öğrencilerinin cinsiyete bağlı olarak liderlik davranışı (yapıyı kurma boyutu) yönünden karşılaştırılması. Gaz̧i Üniversitesi Kırşehir Eğitim Fakültesi Dergisi, 6(1), 25-32.

Erçetin, S. (2000). Lider sarmalında visyon. Ankara: Nobel Yayıncilık.

Gümüşeli, A. İ. (1996). Okul müdürlerinin öğretim liderliğini sınırlayan etmenler. Eğitim Yönetimi, 2(2), 23-,24.

Gündüz, H.B. \& Doğan, A. (2009). Okul yöneticilerinin liderlik stilleri ve yaratıcılık düzeyleri. I. Uluslararası Türkiye Eğitim Araştırmaları Kongresi. Çanakkale 18 Mart Üniversitesi Eŭitim Fakültesi, $\quad 1-3 \quad$ Mayıs $2009 . \quad$ Çanakkale. http://Www.Eab.Org.Tr/Eab/Oc/Egtconf/Pdfkitap/Pdf/263.Pdf.

Hacıfazlıŏlu, Ö., Karadeniz, Ş., \& Dalgıç, G. (2010). Eğitim yöneticileri teknoloji liderliği standartlarına ilişkin öğretmen, yönetici ve denetmenlerin görüssleri [Views of teachers, administrators and supervisors regarding the technological leadership standards for administrators]. Kuram ve Uygulamada Ë̆itim Yönetimi [Educational Administration: Theory and Practice], 16(4), 537-577.

Houghton, J. D. \& Yoho S. K. (2005). Toward a contingency model of leadership and psychological empowerment: When should self-leadership be encouraged? Journal of Leadership ve Organizational Studies, 11, 65-83.

Hughes, W.L. (2005). Transparency, translucence or opacity? an experimeltal study of impact of a leader's relational transparency and style of humor delivery on follower creative performance. A Disertation Presented To The Faculty Of The Graduate College At Teh University Of Nebraska Fro The Degree Of Doctor Of Philosophy Agust UMI NUMBER 3186859.

Jaussi, K.S. \& Dionne, S. D. (2003). Leading for creativity: The role of unconventional leader behavior. The Leadership Quarterly, 14, 475-498.

Karakaya, İ. (2012). Bilimsel araştırma yöntemleri. A. Tannı̈ğen (Ed.) Bilimsel araștırma yöntemleri. Ankara: Anı Yayıncilik.

Karasar, N. (2012). Bilimsel araștırma yöntemi. Ankara: Nobel Yayın Dağıtım.

Khim, B. S. P. (2003). Developing quality indicators of preschool education programme in singapore. 1-36. 18.04.2009. Erişim adresi (15 Mart 2009): http://www.alsauc.edu.sg/article/article_030801_RCF1.pdf. 
Koçel, T. (2007). Issletme yöneticiliği, yönetim ve organizasyon, organizasyonlarda davranıss, klasik-modern-çağdas ve güncel yaklassımlar. (11. Basim) İstanbul: Beta Yayıncilik.

Litchka, P. R., Babaoğlan, E. \& Beycioğlu, K. (2009). Gender perceptions of the leadership abilities of principals in turkey and the united states. Paper presented at the First International Congress of Educational Research. Çanakkale, Turkey May 1-3.

Mandell, B. \& Pherwani S. (2003). Relationship between emotional intelligence and transformational leadership style: a gender comparison. Journal of Business and Psychology, 17(3), 387-404.

Marşap, A. (1999). Yaratıcı liderlik. Ankara: Öncü Kitap.

Moolenaar, N. M, Daly, A. J. \& Sleegers P.J. C. (2010). Occupying the principal position: examining relationships between innovative climate transformational leadership, social network position, and schools' innovative climate. Educational Administration Quarterly, 46, 623-670.

Morland, M, P. (2008). Systemic leadership and the emergence of ethical responsiveness. Journal of Business Ethics, 82: 509-524.

Mueller, J.S., Goncalo, J.A, Dishan \& Kamdar, D. (2011): Recognizing creativeleadership: can creative idea expression negatively relate to perceptions of leadership potential? Journal of Experimental Social Psychology, 47(2), 494-498.

Mumford, M., D., Shane C. \& Gaddis, B. (2003). How creative leaders think: experimental findings and cases. The Leadership Quarterly. 14, 411-432.

Özalp, İ. (1999). Kendi kendini yöneten ekiplerde liderlik. Anadolu Üniversitesi İktisadi ve İdari Bilimler Fakültesi Dergisi, 15(1-2), 53-64.

Pounder J. S. (2006).Transformational classroom leadership the fourth wave of teacher leadership? Educational Management Administration \& Leadership Belmas 34(4), 533-545.

Rickards, T. \& Susan Moger, S. (2000). Creative leadership processes in project team development: an alternative to tuckman's stage model. British Journal of Management, 11, 273-283.

Shin, M. S., Recchia S. L., Lee S. Y., Lee, Y. J. \& Mullarkey, L. S. (2004). Understanding early childhood leadership emerging competencies in the context of relationships. Journal of Early Childhood Research October, 2(3), 301-316.

Sisk, D. A. (2001). Creative leadership: A study of middle managers, senior level managersand CEOS. Gifted International, 15 (3), 281-290. 29 Mart 2009 tarihinde http://dept.lamar.edu/connchair/ web adresinden erişildi.

Sternberg, R J. (2005). WICS: A model of positive educational leadership comprising wisdom, intelligence, and creativity synthesized. Educational Psychology Review, 17(3), 191-262.

Stoll, L. \& Temperley, J. (2008) 'Creative leadership learning project - an enquiry project for senior leadership teams and local authority officers in South Gloucestershire: final report' (Unpublished report). Creating Capacity for Learning and South Gloucestershire LA.

Stoll, L., \& Temperley J. (2009). Creative leadership teams capacity building and succession planning. British Educational Leadership, Management ve Administration Society (Belmas), 23(1): $12-18$.

Tahaoğlu, F. \& Gedikoğlu, T. (2009). İlköğretim okulu müdürlerinin liderlik rolleri. Kuram ve Uygulamada Ë̈itim Yönetimi, 15(58), 274-298.

Taş, A. \& Çetiner, A. (2011). Ortaöğretim okulu müdürlerinin dönüşümcü liderlik davranışlarını gerçekleştirme durumlarına ilişkin öğretmen görüşleri. Türk Eğitim Bilimleri Dergisi, 9(2), 369392. 
Taymaz, H. (2003). Okulyönetimi. İstanbul: Pegem Yayıncllı.

Tengilimlioğlu, D. (2005). Kamu ve özel sektör örgütlerinde liderlik davranışı özelliklerinin belirlenmesine yönelik bir alan çalısması. Elektronik Sosyal Bilimler Dergisi, 4(14), 1-16.

Titrek, O., Bayrakçı, M \& Zafer, D. (2009). Okul Yöneticilerinin duygularını yönetme yeterliklerine ilişkin okul yöneticisi ve öğretmenlerin görüşleri. Mehmet Akif Ersoy Üniversitesi Eğitim Fakültesi Dergisi, 9(18), 55-73.

Turan, S. \& Ebiçlioğlu, N. (2002). Okul müdürlerinin liderlik özelliklerinin cinsiyet açısından değerlendirilmesi. Kuram ve Uygulamada Eğitim Yönetimi, 31, 444-458.

Vandenberghe, R. (1995) "Creative management of a school: a matter of vision and daily interventions". Journal of Educational Administration, 33(2), 31 - 51

Vural, Ö. (2008). Okul öncesi eğitim kurumu yöneticilerinin liderlik özellikleri ve empatik becerilerinin incelenmesi. Yayınlanmamıs Yüksek Lisans Tezi, Ankara Üniversitesi, Fen Bilimleri Enstitüsü, Ankara.

Yamaguchi, R. (2004). Children's emergent leadership the relationships with group characteristics and outcomes. Small Group Research, 35(4), 388-406.

Zembat, R. (2001). Nitelik açısından okul öncesi eğitim kurumlar ve ilgili bir araştırma. İstanbul: Marmara Üniversitesi Döner Sermaye İşletmesi Teknik Eğitim Fakültesi Matbaa Birimi.

Zembat, R. (2005). Okul öncesi eğitimde nitelik. A. Oktay \& Ö. Polat Unutkan (Ed.) Okul öncesi eğitimde güncel konular (s.25-45). İstanbul: Morpa Yayınlar1. 